UNIVERSIDADE DE BRASÍLIA - UnB

Instituto de Relações Internacionais

IX Curso de Especialização em Relações Internacionais

A Política Externa de Boa Vizinhança dos Estados Unidos para América Latina no contexto da Segunda Guerra Mundial

Isaias Albertin de Moraes

Brasília

Março de 2008 
Isaias Albertin de Moraes

A Política Externa de Boa Vizinhança dos Estados Unidos para América Latina no contexto da Segunda Guerra Mundial

\begin{abstract}
Monografia apresentada como requisito parcial à obtenção do título de Especialista em Relações Internacionais, pelo Instituto de Relações Internacionais da Universidade de Brasília UnB.
\end{abstract}

Professor orientador: Antônio Carlos Lessa

Brasília 
Agradeço ao professor e orientador Antônio Carlos Lessa pelo apoio, pelo profissionalismo, pela dedicação e pela paciência ao me acompanhar na elaboração deste trabalho; aos demais professores da casa pelos conhecimentos transmitidos e aos coordenadores e aos colaboradores do IX Curso de Especialização em Relações Internacionais da Universidade de Brasília pelo apoio institucional e pelas facilidades oferecidas. 


\section{RESUMO}

Este trabalho apresenta uma análise histórica da Política Externa de Boa Vizinhança para América Latina e do uso dos meios de comunicação, sobre a guarda do Office of the coordinator of Inter-American Affairs - OCIAA, no período do governo de Franklin Delano Roosevelt - 1933 a 1945.

Diante da decisão de qual orientação adotar para a política externa estadunidense, a margem de manobra é grande e diversificada. Saber o porquê e o quê levou o governo de Franklin Delano Roosevelt a ter optado pela Política de Boa Vizinhança, naquela época, possibilita uma melhor compreensão das estratégias utilizadas na elaboração da política externa de um país.

Dessa forma, a identificação das principais características e dos objetivos da Política Externa de Boa Vizinhança e do OCIAA contribui para a melhoria do processo de construção de uma política externa diversificada e eficiente.

Este estudo, como quase todas as pesquisas exploratórias, foi desenvolvido com o objetivo de proporcionar uma visão geral sobre uma determinada realidade. Sendo assim, a metodologia adotada consistiu na pesquisa bibliográfica, bem como na pesquisa histórica. Foi realizada uma abordagem sistemática por meio de coleta, organização e avaliação crítica de dados históricos, de fontes secundárias, tais como: livros, revistas, jornais, filmes, fotografias, anúncios publicitários, entre outros. As interpretações dos dados foram feitas de forma qualitativa.

Palavras chaves: Política Externa de Boa Vizinhança; Brasil; Segunda Guerra Mundial; Office of the coordinator of Inter-American Affairs - OCIAA; meios de comunicação. 


\section{SUMÁRIO}

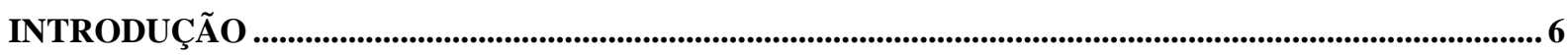

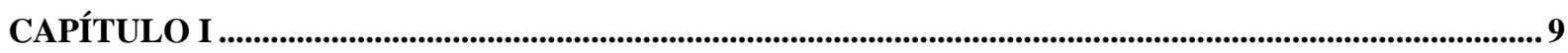

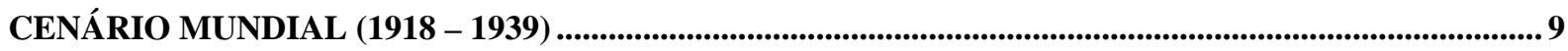

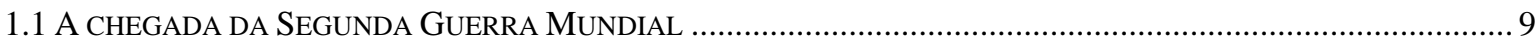

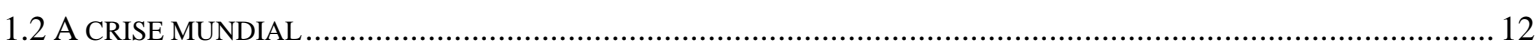

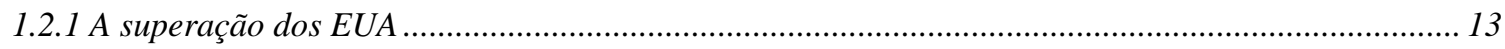

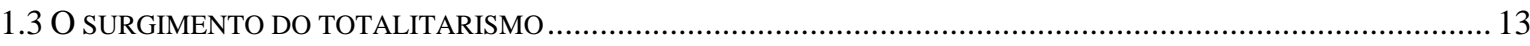

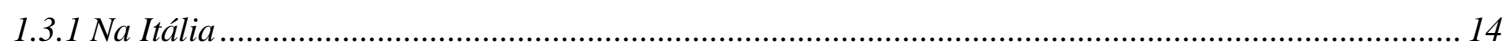

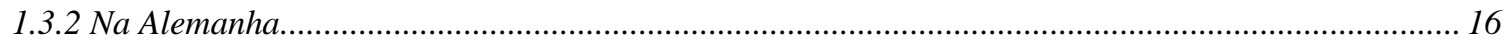

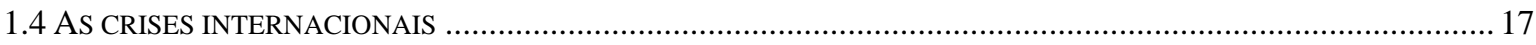

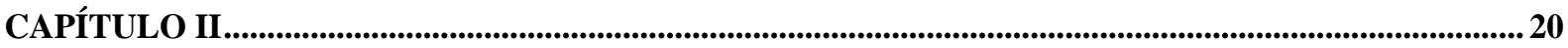

O BRASIL (1930 - 1945) ............................................................................................................................ 20

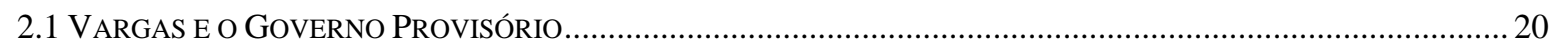

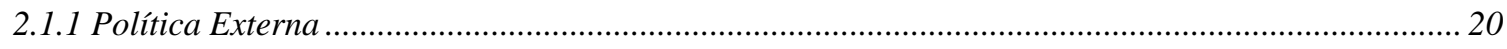

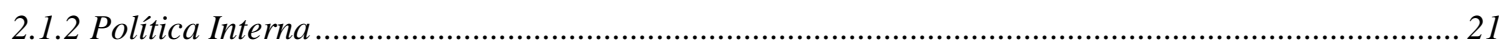

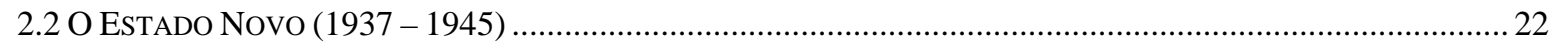

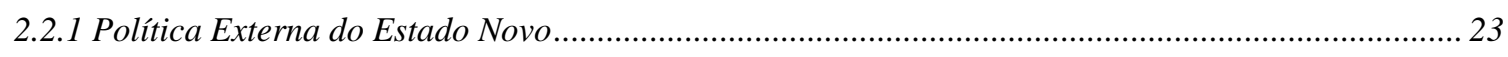

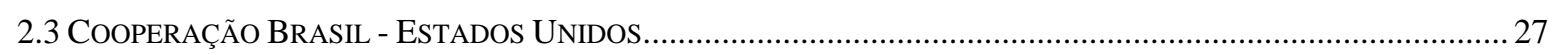

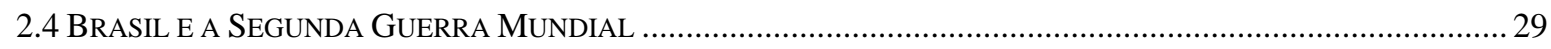

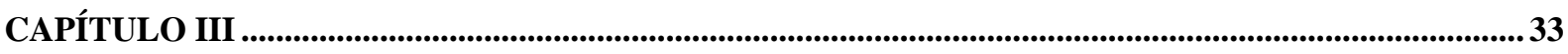

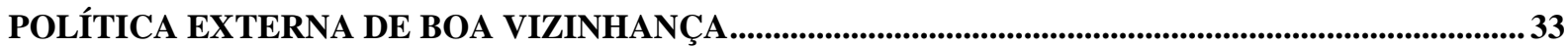

3.1 Antecedentes da Política Externa de Boa VizinhanÇA ............................................................... 33

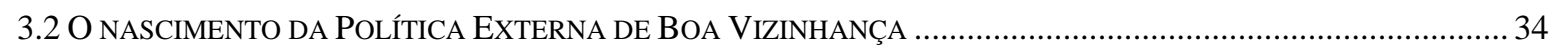

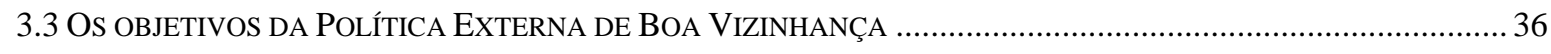

3.4 A CRIAÇÃO DO OFFICE OF THE COORDINATOR OF INTER-AMERICAN AFFAIRS - OCIAA .............................. 39

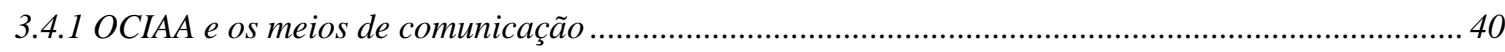

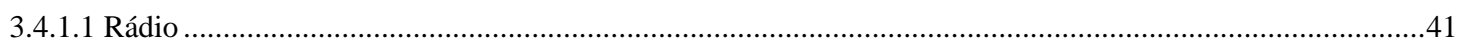

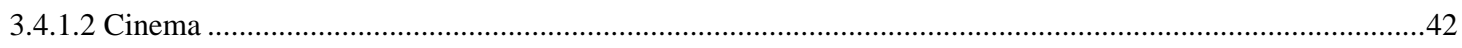

3.5 O FIM DO OCIAA E DA POLÍTICA EXTERNA DE BOA VIZINHANÇA .................................................................... 44

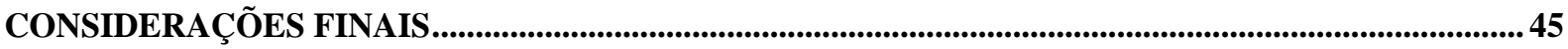

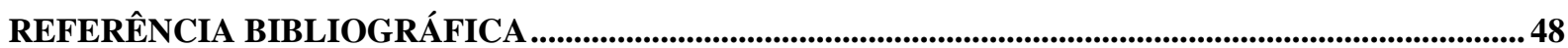




\section{INTRODUÇÃO}

A realização de uma pesquisa que contextualize e identifique as principais características da Política Externa de Boa Vizinhança para América Latina - no período do governo de Franklin Delano Roosevelt - 1933 a 1945, e que demonstre o importante papel dos meios de comunicação, nesse período, sobre a guarda do Office of the coordinator of Inter-American Affairs - OCIAA, justifica-se e encontra sua relevância no que diz respeito ao melhor aproveitamento e conhecimento das formas de políticas externas outrora usada e atualmente deixada, muitas vezes, em segundo plano.

A identificação das principais características e dos objetivos da Política Externa de Boa Vizinhança e do OCIAA contribui para a montagem do processo de construção de uma política externa diversificada. Além disso, lança luzes sobre o passado para que esse possa clarear o uso dos meios de comunicação - por meio da atração do soft power ${ }^{1}$ - a adoção da política de aproximação e da consolidação de laços econômicos duradouros em detrimento ao hard power ${ }^{2}$ e à “diplomacia de canhoneiras.”

Este estudo, como quase todas as pesquisas exploratórias, foi desenvolvido com o objetivo de proporcionar visão geral sobre uma determinada realidade. Sendo assim, enveredou-se pela linha da pesquisa bibliográfica. Essa se desenvolveu a partir de material já elaborado, constituído principalmente de estudos acadêmicos e obras de autores de grande saber notório sobre o assunto.

Na primeira parte, a pesquisa realizará uma breve contextualização histórica do cenário mundial da época estudada. A análise das condições histórico-sociais da sociedade, daquele período, é um importante passo para compreender em que condições se encontravam as forças sociais, pois a comunicação e as relações internacionais não podem ser estudadas fora do contexto econômico, social, político e cultural que as envolvem. Dessa forma, o primeiro capítulo é importante para se compreender melhor os fatores responsáveis pelo surgimento das crises internacionais do período entre guerras (1919 - 1939) e a própria Segunda Guerra Mundial. Ele foi dividido em quatro partes. Na primeira, apresentam-se algumas das razões que possibilitaram a chegada da Segunda Guerra Mundial. Na segunda

\footnotetext{
${ }^{1} \mathrm{O}$ termo soft power foi popularizado por Joseph Nye (Nye, Jr. Joseph S. "Soft Power: The Means to Success in World Politics". Public Affairs, 2004.) O autor descreve tal poder como "a habilidade de obter o que você quer, atraindo e persuadindo os outros a seguirem objetivos seus”. (MUNDORAMA, 2005).

${ }^{2} \mathrm{O}$ termo hard power, descrito por Joseph Nye (Nye, Jr. Joseph S. "Soft Power: The Means to Success in World Politics”. Public Affairs, 2004.), corresponde ao poder militar tradicional. (PECEQUILO, 2003, p.04)
} 
parte, analisa-se o famoso Crack da bolsa de valores nova-iorquina - 1929 e seus efeitos tanto nos Estados Unidos da América - EUA quanto mundial. Demonstra-se o surgimento do presidente estadunidense Franklin Delano Roosevelt e de seu plano, denominado New Deal, como as grandes esperanças para solucionar os efeitos da Crise. Na terceira parte, apresentase o surgimento das formas totalitárias de governo. Esses, aproveitando o período turbulento de entre guerras, surgem na Europa e em outras regiões com fortes objetivos militaristas e expansionistas. Os regimes totalitários colocavam em “xeque” os governos democratas liberais vigentes, pois defendiam o fortalecimento do poder executivo e a eliminação das tendências individualistas liberais. O fascismo italiano e o nazismo na Alemanha servem como ilustração, nesse capítulo, para o entendimento dos fatores, das razões que possibilitaram seus surgimentos e o modo de pensar desses regimes. Por último, é feita uma breve análise das ações, tanto diplomáticas quanto militares, que funcionaram como molas propulsoras para o inicio da Segunda Guerra Mundial.

Em um segundo momento, o cenário brasileiro, a partir da chegada de Getúlio Vargas ao poder e os seus anos seguintes (1930 - 1945), é o destaque. Dividido, também, em quatro partes, o capítulo dois apresenta, primeiramente, o fim da República Velha e a chegada de Vargas ao poder. Ademais, a política externa do Governo Provisório e Constitucional de Vargas (1930 - 1937) e o cenário político interno são apresentados brevemente. Na segunda parte, analisa-se o surgimento da ditadura do Estado Novo (1937 - 1945) em um momento histórico internacionalmente favorável aos regimes totalitários. Depois disso, é feita uma reflexão da política externa do Estado Novo e a adoção de Vargas por um “jogo duplo” e de sua “eqüidistância pragmática” (MOURA, 1980, p.135) em relação aos Estados Unidos e à Alemanha. Por último, especifica-se a relação bilateral dos EUA com Brasil e as principais características das negociações da cooperação brasileira nos esforços de guerra em favor dos Aliados. Na quarta e última parte, desse capítulo, apresenta-se as diferentes formas de participação do Brasil na Segunda Guerra Mundial e sua conseqüência para a política externa e interna brasileira.

O terceiro capítulo é divido em cinco partes. Na primeira delas, analisam-se alguns aspectos das políticas externas estadunidenses que antecederam a da Boa Vizinhança para a América Latina. Isso permite que, na segunda parte, apresentam-se o contexto histórico e econômico dos países latino-americanos e o surgimento da Política Externa de Boa Vizinhança. Na terceira parte, especificam-se os objetivos e as metas dessa política externa dos EUA. A análise da criação do Office of the coordinator of Inter-American Affairs OCIAA se faz na quarta parte. Essa cuida de especificar o funcionamento do OCIAA, 
principalmente do departamento de comunicação. Levantam-se, nessa parte, alguns parâmetros fundamentais do uso dos meios de comunicação, principalmente cinema e rádio, para além de seu caráter informativo e sua função de entretenimento. Faz-se a reflexão do geral, sobre esses meios de comunicação, como forma de exportar em versões idealizadas o American way of Life e a clara tentativa de influenciar a audiência latino-americana por meio da atração do soft power. Encerrado o capítulo, a quinta parte apresenta o fim da Política Externa de Boa Vizinhança e do OCIAA - com o término da Segunda Guerra Mundial e da ameaça nazi-fascista na América - e o surgimento de uma nova ordem mundial.

Enfim, de posse desse conjunto de elementos, é possível estabelecer, no período em questão, a importância e a relevância da elaboração de uma política externa diversificada, que leva em consideração, no seu processo de construção, a multiplicidade de relações e todos os meios e as esferas possíveis para atingir seus objetivos e suas metas. 


\section{CAPÍTULO I}

\section{CENÁRIO MUNDIAL (1918 - 1939)}

\subsection{A chegada da Segunda Guerra Mundial}

A década de 30 do século passado, período que o democrata Franklin Delano Roosevelt chega ao cargo de presidente dos Estados Unidos da América, foi uma época turbulenta na história da civilização ocidental. Crise econômica a partir de 1929, ano da quebra da bolsa de valores de Nova Iorque, com desemprego generalizado e redução das transações internacionais. A Crise de 29 foi tão séria que comprometeu a própria teoria econômica e o papel do mercado enquanto agente econômico. Desde a década de 1920, com o fim da hegemonia inglesa e a desestruturação do equilíbrio europeu, o mundo também enfrentava uma crise política, comprometendo as formas de poder político e de regime de governo. Além disso, havia os acordos que puseram fim à Primeira Guerra Mundial e que não tiveram os efeitos esperados.

Os resultados da Conferência de Paz em Paris - 1919 colocaram fim ao concerto dos europeus e introduziram uma nova divisão na Europa Continental. Essa opunha o grupo de países satisfeitos com os acordos (França, Tchecoslováquia, Iugoslávia, Romênia e Polônia) ao dos insatisfeitos (Alemanha, Áustria, Hungria, Turquia e Itália). Os países descontentes queriam a revisão das fronteiras e até mesmo a demolição da ordem versalhina. (SARAIVA, 2007, p. 133).

Nota-se que as relações internacionais, no período entre guerras - 1919 a 1939, foram marcadas por contínuas crises políticas e econômicas. O Tratado de Versalhes, assinado em 1919 na Conferência de Paris, não conseguira promover a paz e a segurança mundial. A ordem de Versalhes era um tanto incoerente, defeituosa e pouco realista. (SARAIVA, 2007, p.135).

A Sociedade das Nações, organização internacional criada pelo Tratado de Versalhes, era um pacto nascido da idéia da solução pacífica de controvérsias e de cooperação internacional. Ela fracassou ao tentar estabelecer acordos entre vencidos e vencedores e ao satisfazer as aspirações nacionais de cada país membro. A Sociedade das Nações tinha 
algumas deficiências que a limitava bastante como: a falta de força militar efetiva, a incerteza sobre se a paz deveria ser assegurada pela manutenção ou pela revisão do Tratado de Versalhes e a ausência de potências, a União das Repúblicas Socialistas Soviéticas - URSS, os Estados Unidos da América - EUA e a Alemanha. (SARAIVA, 2007, p.142). Pode-se afirmar que o Tratado de Versalhes e a criação da Sociedade das Nações foram tentativas desesperadas, das potências vitoriosas, para evitar uma nova guerra, como a que acabara de ocorrer. Todavia, essas fracassaram, pois, vinte anos depois, o mundo estava de novo em guerra. (HOBSBAWM, 1995, p.39 - 40).

Ademais, havia a questão das reparações da Primeira Guerra Mundial imposta na Conferência de Paris à Alemanha, derrotada, que não tinha condições de arcá-las. Segundo Hobsbawm, os vencedores impuseram à Alemanha uma paz punitiva, ou seja, o Estado alemão foi considerado o único responsável pela guerra e suas conseqüências, sendo assim, ele deveria ser punido e pagar pelos seus atos. (HOBSBAWM, 1995, p.41).

Apesar da participação do presidente estadunidense Woodrow Wilson, no início das negociações, os EUA não ingressaram na Sociedade das Nações. O Senado estadunidense convenceu-se de que seria melhor para os EUA voltarem ao seu isolacionismo e não se envolverem nos atritos da Europa e mantê-la longe da América. (SARAIVA, 2007, p.134).

Os EUA, com sua cultura progressista, haviam passado de devedores dos europeus, antes da guerra, para credores de diversos países, ou seja, o centro das relações comerciais internacionais estava nos EUA. (HOBSBAWM, 1995 p.95). Ademais, além de terem a supremacia comercial e financeira, eles eram a primeira potência industrial do mundo desde 1914. Percebe-se que a Primeira Guerra Mundial provocou uma mudança nas posições de certas nações como potências econômicas. (SARAIVA, 2007, p.135).

A partir de 1922, quando a França e a Inglaterra saldaram seus débitos com os EUA - ato que somente foi colocado em prática à medida que os alemães pagaram as reparações de guerra para esses países, houve expansão da indústria de produção de bens de consumo estadunidense. Em 1924, os EUA passaram a colaborar com a recuperação da economia alemã, fazendo investimentos no país, garantindo, assim, o pagamento das reparações e conseqüentemente das dívidas da época da guerra. Esse período, do ano de 1921 até a Crise de 29, ficou caracterizado pelo grande desenvolvimento tecnológico, pelo grande aumento da produção em novas áreas - como a automobilística, pela geração de emprego e pela elevação do nível de consumo das camadas médias urbanas. (SARAIVA, 2007, p.135).

Contudo, quando a Europa se recuperou e adotou medidas protecionistas para reerguer sua indústria, a superprodução, principalmente de grãos, estadunidense não 
encontrou mais mercado e os preços começaram a cair. Na década de 1920, havia ainda uma forte especulação financeira no mercado estadunidense. Como as empresas estavam obtendo altos lucros, suas ações tenderam a crescer, originando sociedades anônimas e empresas responsáveis apenas por gerir e investir dinheiro. Em 1925, o valor total de títulos cotados na Bolsa de Valores de Nova Iorque era de 27 milhões de dólares. Esse número saltou, em 1929, para 87 milhões de dólares, o que não correspondeu a um aumento proporcional do valor das empresas representadas por esses títulos, nem os lucros correspondentes. (MILZA, 1996, p.129).

Esses e outros fatores foram responsáveis pela crise internacional do capitalismo de 1929, mas é difícil de encontrar somente uma razão para a Grande Depressão. Houve várias razões e elas são extremamente complexas, havendo divergências entre historiadores e economistas sobre qual importância de cada fator. (MILZA, 1996, p.127).

O primeiro sinal da crise foi no campo. Os agricultores estadunidenses, baseando-se nos altos preços do mercado internacional, buscaram financiamentos para expansão das propriedades e para mecanização da produção. À medida que as exportações diminuíram, os grandes proprietários não conseguiram saldar as dívidas realizadas no período da euforia. Além disso, eram forçados a pagar altas taxas para armazenar seus grãos, acumulando dívidas que os levaram à falência. A crise no campo refletiu-se nas cidades com o desabastecimento de produtos. A crise na produção básica de alimentos e matérias-primas ocorreu porque os preços caíram de forma drástica em razão de não serem mais mantidos pela formação de estoques como antes. (HOBSBAWM, 1995, p.96).

Ademais, a mecanização crescente da indústria começou a provocar a dispensa de operários, resultando no aumento do índice de desemprego. Concomitantemente a isso, houve aumento, por parte do empresariado, das especulações com ações de empresas que aumentavam ficticiamente seus valores. A súbita alta dessas, durante 1929, provocou a desconfiança dos investidores que lançaram seus títulos à venda no final de setembro do mesmo ano. Wall Strett estava em declínio e, em 24 de outubro de 1929, milhões de títulos não encontraram compradores. A desvalorização dos papéis levou bancos e empresas à falência e fez cair os preços dos principais produtos industrializados e agrícolas. Formou-se, então, um círculo vicioso nos EUA: queda de exportações, superprodução, menor lucro, diminuição da produção, desemprego, baixo consumo interno, retração dos investimentos, mais mão de obra ociosa, maior queda no consumo e assim sucessivamente até a queda da Bolsa de Nova Iorque em 1929. 
Em suma, a Crise de 29 foi resultado, principalmente, da interdependência e da superprodução - tanto agrícola quanto industrial, gerada em razão de o mercado interno estadunidense não conseguir mais absorver a oferta criada para atender a demanda nos tempos de guerra.

\subsection{A crise mundial}

A crise se estendeu rapidamente pelo mundo, em razão da interdependência do sistema capitalista. Dessa forma, todos os países ligados à economia estadunidense sofreram repercussões. Cada país foi afetado de acordo com o grau de dependência de sua economia no comércio internacional.

Ademais, os EUA eram o maior credor dos países europeus e da América Latina, e passaram a exercer forte pressão no sentido de repatriação dos capitais emprestados. Logo, a saída dos capitais estadunidenses da Europa provocou uma série de falências. Na América Latina, o abastecimento do mercado foi afetado e a quebra industrial provocou a falta de produtos, a elevação de preços e a queda das importações dos EUA. Países produtores de matérias-primas, como o Brasil e a Argentina, tiveram suas exportações drasticamente afetadas.

No Brasil, para evitar a queda do preço do café, os cafeicultores queimavam parte de sua safra, em vez de carvão, nas locomotivas a vapor. Isso demonstrava a seriedade da Grande Depressão e tornou-se um símbolo do desperdíco do capitalismo. (HOBSBAWM, 1995, p.97). Somente a Rússia que se tornara socialista em 1917 não sofrera conseqüências da Crise de 1929.

Naquele período, várias nações do mundo atravessavam por problemas sociais profundos como desemprego em massa, miséria, antagonismo social, entre outros. Algumas pessoas e grupos começaram questionar e discutir a própria forma do Estado. O mundo capitalista assistia à descrença nas instituições e ao crescimento das manifestações nacionalistas. A busca por alternativas radicais para combater a crise tornava-se cada vez mais atrativa. (SARAIVA, 2007, p.145).

O sistema capitalista e a sua forma liberal estavam em debate. O individualismo, a livre iniciativa e a regulamentação econômica somente pelo mercado perdiam espaço para o nacionalismo econômico, o protecionismo alfandegário e a autarcia política (SARAIVA, 
2007, p.145). Estaria a democracia em condições de resolver a crise? Ou a ditadura fascista seria o melhor caminho? Realmente o capitalismo liberal seria a melhor forma de se organizar a economia? Questões como essas começaram a ser recorrente naquele período.

\subsubsection{A superação dos EUA}

Com a promessa de combater os efeitos alarmantes da Crise de 1929, o democrata Franklin Delano Roosevelt foi eleito presidente dos EUA em 1932. Ele colocou em prática um conjunto de medidas políticas e econômicas que reformularam o papel do Estado na economia. Essas medidas, baseadas nas idéias do economista inglês John Maynard Keynes, ficaram conhecidas como New Deal.

O New Deal (novo tratamento) foi uma nova distribuição do papel do Estado na economia capitalista. A conclusão de Roosevelt e de sua equipe era de que a crise tinha ocorrido em razão de uma má distribuição dos rendimentos e das riquezas. Dessa forma, o Estado deveria controlar e coordenar as atividades econômicas para que essas fossem mais bem distribuídas e eficientes. Apesar desse aspecto intervencionista da economia, o New Deal respeitava a iniciativa individual e a propriedade dos meios de produção. (MILZA, 1996, p.144).

Percebe-se que com o New Deal, o governo estadunidense deixava de seguir as idéias liberais, como fizera até então, e passava a praticar o intervencionismo econômico. Lentamente e com grande dificuldade, em razão da extensão da crise, o plano conseguiu fazer com que a economia dos EUA voltasse a crescer.

Ademais, infere-se que a Crise de 1929 foi responsável pela descrença no liberalismo econômico por aproximadamente meio século. (HOBSBAWM, 1995, p.99).

\subsection{O surgimento do totalitarismo}

É neste período turbulento de entre guerras que os governos de caráter totalitário surgem na Europa e em outras regiões com fortes objetivos militaristas e expansionistas. 
O Japão, a Itália e a Alemanha, potências revisionistas do Tratado de Versalhes, iniciaram políticas exteriores agressivas contra Estados mais fracos (China, Etiópia e Tchecoslováquia, respectivamente) de meados dos anos trinta até setembro de 1939. Concomitantemente a isso, elas começaram a se aproximar uma das outras, diplomática e politicamente. (ALVES, 2002, p.16).

Nota-se que as perturbações políticas e econômicas do pós-guerra levaram ao poder, em determinados países, forças políticas do militarismo e da extrema direita. Essas lutavam pela mudança do status quo internacional mais pelo confronto, se necessário militar, do que pela via diplomática. (HOBSBAWM, 1995, p.43).

As democracias estavam ameaçadas por regimes de caráter totalitário tanto pela direita, fascista, quanto pela esquerda, comunista. O avanço dos regimes totalitários se deu muito, primeiramente, pelos traumas deixados pela Primeira Guerra Mundial e, posteriormente, pela Crise de 1929 na população européia. Essa buscava, naquele momento, segurança em ideologias que correspondiam a reservas estruturadas de idéias e valores. Sabendo disso, partidos políticos, intelectuais e militantes aproveitavam esse tremor ideológico e psicológico que afetava a mentalidade coletiva na Europa para influir sobre os outros. (SARAIVA, 2007, p.137).

A Alemanha, derrotada na Primeira Guerra, e a Itália, vitoriosa, mas insatisfeita com os acordos estabelecidos em Paris, viviam em situação crítica. Ambos os países sofriam com forte desemprego, com greves e com inflação galopante. Esse cenário possibilitou a oposição aos governos liberais vigentes e o nascimento de partidos ultranacionalistas, que defendiam o fortalecimento do poder executivo, a eliminação das tendências individualistas liberais e a eliminação do coletivismo comunista.

\subsubsection{Na Itália}

A Itália que, primeiramente, não se envolveu diretamente na Primeira Guerra, acabou auxiliando a Entente - Inglaterra, França e Império Russo, que prometera a ela que, ao final da Guerra, receberia o território do Tirol e parte das colônias alemãs. Todavia, com o final do conflito, a Itália não conseguiu anexar todos os territórios que pretendia, como a Dalmácia e as colônias alemãs da África. Isso gerou insatisfação e ressentimento nacional, 
provocando a exaltação nacionalista e um desejo maior de conquistas territoriais entre os italianos.

O sentimento nacionalista só aumentava com a caótica situação econômicofinanceira do país, agravada pela emissão sem precedentes de papel moeda e pelos problemas de superpovoamento. A crise social adquiriu um aspecto revolucionário, logo, iniciou-se no país uma prolongada onda grevista. Temerosa da incapacidade do governo de controlar os movimentos grevistas e das inúmeras agitações espontâneas, que culminavam em assaltos a lojas e a armazéns, parte da elite começou a procurar alternativas políticas para restabelecer a ordem na Itália. Com essa finalidade, nasceu a organização paramilitar chamada Fascio di Combattimento, fundada, em Milão, por Benedito Mussolini. Na avaliação de Hobsbawm, o surgimento do fascismo, na Itália, não ocorreu em razão somente da insatisfação pós-guerra, mas foi principalmente em razão do avanço dos movimentos sociais esquerdista.

\begin{abstract}
A ascensão da direita radical após a Primeira Guerra Mundial foi sem dúvida uma resposta ao perigo, na verdade à realidade, da revolução social e do poder operário em geral, e à Revolução de Outubro e ao leninismo em particular. Sem esses, não teria havido fascismo algum, pois embora dos demagógicos ultradireitistas tivessem sido politicamente barulhentos e agressivos em vários países europeus desde o fim do século XIX, quase sempre haviam sido mantidos sob controles antes de 1914. (HOBSBAWM, 1995, p.127).
\end{abstract}

Os socialistas italianos ganhavam espaço organizando greves e tomando algumas fábricas. Diante dessa importância da oposição, do descrédito do regime e da inércia do governo, Mussolini preparou a grande Marcha sobre Roma para tomar o poder por via militar. Em 21 de outubro de 1922, depois de ocuparem edifícios públicos e estações ferroviárias, as esquadras fascistas (camisas negras), vindas de várias regiões italianas, entraram na capital, exigindo o estabelecimento da ordem e a formação de um regime mais forte e estável. Dessa forma, o rei Vítor Emanuel III convocou o próprio Mussolini que, em novembro do mesmo ano, recebeu do parlamento italiano plenos poderes para organizar um novo ministério e controlar as tensões sociais.

Senhor único da Itália, o Duce, passou a governar mediante decretos, pondo em funcionamento um Estado interventor e autoritário. Nascia assim o Estado fascista italiano.

O modelo fascista italiano serviria de exemplo a vários países do mundo, principalmente na Europa Central, que se caracterizava pela ausência de tradição democrática e estava conturbada por crises econômicas e sociais. O fascismo inspirava as forças antiliberais e parecia ser a nova onda do futuro. (HOBSBAWM, 1995, p.116). 
Enfim, o surgimento do fascismo pode ser considerado o acontecimento político mais chocante do período entre os dois conflitos, pois esse levou ao colapso dos valores e das instituições do mundo liberal e rachou a opinião das nações em todo mundo.(SARAIVA, 2007, p.139).

\subsubsection{Na Alemanha}

Com o término da Primeira Guerra Mundial e com a abdicação do imperador Guilherme II, a Alemanha entrou em verdadeiro caos político e econômico. Após diversos acordos, em agosto de 1919, os socialistas democráticos alemães assumiram o governo e instalaram a República de Weimar.

De 1919 até 1929, o governo alemão enfrentou grandes dificuldades. A miséria e a fome se abatiam sobre o país em conseqüência da contínua desvalorização monetária, provocada pela necessidade de pagar indenizações de guerra aos Aliados. As condições impostas pela Inglaterra e, principalmente, pela França sobre a Alemanha, como forma de reparação de guerra, eram muito duras. A Alemanha tinha de pagar uma pesada dívida de guerra e sofria da falta de mão de obra. A crise política e a econômica provocaram descontentamento generalizado e destruía o precário equilíbrio da República de Weimar e trazia a tona velhos antagonismos sociais. (MILZA, 1996, p.198).

A Crise de 29 agravou a situação da Alemanha, pois o país dependia de créditos estadunidenses para saldar seus compromissos internacionais. Esse fluxo de capitais era chamado de o triângulo financeiro da paz, ele vinha dos EUA para Europa e retornava para os EUA. (SARAIVA, 2007, p.144). Entretanto, com a Crise, a circulação de capitais retraiu e a Alemanha sofreu drasticamente.

Em suma, o cenário na Alemanha era de descrédito ao Estado e aos seus mecanismos dirigentes, de fortes movimentos socialistas ameaçando ou parecendo ameaçar com a revolução social e de grande ressentimento nacionalista contra os tratados de paz de 1918 - 20. (HOBSBAWM, 1995, p.130). Foram nessas condições que desempregados, excombatentes e diversas pessoas descontentes com o governo e afetadas pela crise econômica foram atraídas pelo Partido Nacional Socialista - Nazista, cuja principal figura era Adolf Hitler. 
O movimento fascista alemão era muito semelhante ao italiano. Ambos acreditavam em um Estado forte, autoritário e dirigido por um chefe predestinado a guiar a nação. Contudo, Hitler incorporou ao nazismo um elemento novo, a idéia de superioridade da raça germânica às demais.

Em 1933, no governo do marechal Hindenburg, Hitler foi indicado chanceler do parlamento alemão. Em 1934, Hindenburg morreu e Hitler assumiu plenos poderes político e se transformou condutor e guia (Führer) da nação germânica.

As demais nações do mundo demoraram para perceber que a ascensão de Adolf Hitler ao governo alemão, em janeiro de 1933, era um turning point das relações internacionais. Ela significava a vitória do ultranacionalismo e uma nova concepção de relações internacionais, por parte da Alemanha. Essa rejeitava a igualdade dos povos e a dos indivíduos, desprezava os tratados e pretendia dominar pela esperteza ou pela violência. Para tanto, era necessário o rearmamento, as anexações de territórios onde houvesse alemães e a aquisição de vasto "espaço vital” (Lebensraum) para construir a grande Alemanha (Gross Deutschland). (SARAIVA, 2007, p.157).

Uma vez no poder e não havendo outros partidos políticos, esses foram suprimidos por Hitler em 1933, o partido nazista começou uma propaganda massiva, coordenada por Paul Josef Goebbels, para controlar e manipular os cidadãos alemães. Goebbels, para construir a imagem do governo nazista, utilizava a “diplomacia - espetáculo” feito de êxitos chocantes e de grande impactos. (SARAIVA, 2007, p.157).

Como parte dessa propaganda, os discursos de Hitler incitavam o expansionismo, a anulação do Tratado de Versalhes, a devolução das colônias alemãs e a restituição dos territórios perdidos, especialmente aqueles onde havia cidadãos germânicos. Era a idéia do espaço vital em ação, ou seja, as nações que não se expandem são decadentes e fracas.

Conclui-se que a Alemanha, sobre a dominação de Hitler e do partido nazista, pretendia quebrar a ordem de Versalhes, atenuar as perdas territoriais, as reparações e os limites à sua soberania impostos na Conferência de Paris. (SARAIVA, 2007, p.138).

\subsection{As crises internacionais}

Os vinte anos que separam a assinatura do Tratado de Versalhes do desencadeamento da Segunda Guerra Mundial podem ser divididos em três fases: as duas 
primeiras, até 1930, é o entre-guerras. A partir de 1931 - 33, já é o pronunciamento de outra guerra. A política de força dos regimes totalitários e as crises econômicas oriundos de 1929 explicam o último período, a própria guerra.

Infere-se que, com a "colaboração" da Crise de 29, Hitler se transformou em um fenômeno político alemão e posteriormente internacional.(HOBSBAWM, 1995, p.133). Ademais, o desenvolvimento do militarismo, a ineficiência da Sociedade das Nações e as agressões dos regimes totalitários são responsáveis imediatos pelas crises internacionais e pela falência da paz.

No Japão, a subida ao poder de um grupo militar de tendência fascista dá início a uma série de agressões. A conquista da Manchúria e a retirada do país da Sociedade das Nações foram complementares, em 1941, com o ataque à base dos EUA de Pearl Harbor. Quando o Japão invadiu a Manchúria, a Sociedade das Nações protestou, mas o Japão retirouse da Sociedade e essa nada pôde fazer para evitar a agressão. (SARAIVA, 2007, p.167).

Na Itália, a agressão fascista foi iniciada com a invasão da Etiópia (1935 - 36), o que garantiria fontes de matérias-primas e colocação de excedentes populacionais. A retirada do país da Sociedade das Nações, a agressão à Albânia e à Grécia levaram a Itália a entrar definitivamente na guerra em 1940.

Na Alemanha, tendo definido e consolidado sua posição, Hitler parte para o campo das relações internacionais. Em 1933, demonstrando seu desejo de remilitarizar o país, retirou-se da Conferência de Desarmamento de Genebra e da Sociedade das Nações. A partir de 1935, reconstituiu o exército alemão e incorporou Sarre por meio de um plebiscito. (HOBSBAWM, 1995, p.147).

Além disso, em 1936, favorecido pelo pacto anglo-germânico do mesmo ano, iniciou o rearmamento naval, remilitarizou Renânia, firmou com Mussolini o Pacto ítalo-germânico, assinou com o Japão o Pacto Antikomintern - que tinha como objetivo combater o comunismo - e deu início à participação alemã na Guerra Civil Espanhola (1936 - 39). Com Alemanha e Itália auxiliando Franco nos combates espanhóis, esse venceu e implantou, na Espanha, um regime de governo semelhante ao italiano. Vale ressaltar que na Guerra Civil Espanhola tanto a Inglaterra quanto a França declararam-se neutras, logo, colaboraram com a vitória de Franco. (HOBSBAWM, 1995, p.147 - 148).

Em 1938, Hitler anexou a Áustria, iniciando o projeto de formação da Grande Alemanha, ademais, no mesmo ano, exigiu da Tchecoslováquia a entrega da região dos Sudetos, ocupados por alemães. Diante desse avanço alemão, as potências européias não reagiram, aliás, cederam aos anseios de Hitler e sacrificaram os tchecos. Depois de tantos 
esforços para evitar o refortalecimento da Alemanha, as democracias européias não reagiram aos avanços de Hitler.(SARAIVA, 2007, p.165).

A Alemanha com sua política expansionista e militarista violava o Tratado de Versalhes. Como resposta, as principais democracias européias ocidentais, Inglaterra e França, tentavam colocar em prática a "política de apaziguamento", acreditando que dessa maneira conseguiriam frear a expansão do nazismo, por meio da definição de fronteiras européias e da declaração anglo-alemã e franco-alemã de não agressão. Os EUA proclamavam o neutralismo e a URSS estava isolada. Entretanto, em $1^{\circ}$ de setembro de 1939, com a invasão da Polônia por forças alemãs, que reivindicavam o corredor polonês e a cidade de Dantzig, a guerra se tornou inevitável. No dia 3 do mesmo mês, França e Reino Unido abandonaram a política do apaziguamento e cumpriram o prometido - auxiliar a Polônia, assim, declararam guerra à Alemanha. (ALVES, 2002, p.77- 82).

Apesar de haver discórdias entre os historiadores sobre o ano de início da Segunda Guerra, costuma-se adotar o ano de 1939. Todavia, segundo o historiador Alves, não se pode definir uma data precisa. Ele afirma:

\footnotetext{
Acredito, no entanto que é melhor entendermos a Segunda Guerra como um processo que durou aproximadamente uma década, e durante o qual relações mais e mais antagônicas entre as principais potências mundiais terminaram por desaguar num verdadeiro conflito total e global. (ALVES, 2002, p.16).
}

Conclui-se que o avanço do poder alemão sobre os países da Europa Central e a invasão da Polônia pelas forças nazistas são resultados da segunda tentativa alemã para alcançar a supremacia na Europa. A Alemanha, mais uma vez, estava questionando o status quo do sistema internacional e buscava um "lugar ao sol” naquela ordem internacional que se tornava cada vez mais planetária. (ALVES, 2002, p.82). Além disso, o período entre guerras (1918 - 1939) foi nada mais que um período preparatório para um novo conflito que, todavia, envolveria a maior parte das nações do mundo desta vez. 


\section{CAPÍTULO II}

\section{O BRASIL (1930 - 1945)}

\subsection{Vargas e o Governo Provisório}

O período do presidente estadunidense Franklin D. Roosevelt (1933 - 1945) e o da sua Política Externa da Boa Vizinhança coincidem, grosso modo, com a era Getúlio Vargas (1930 - 1945) e o Estado Novo no Brasil.

A deposição de Washington Luiz, que marcou o fim da República Velha, trouxe ao poder o líder do movimento revolucionário, Getúlio Vargas. Sua administração inicia-se com a Lei Orgânica de 11 de novembro de 1930, que definia as atribuições do novo governo. Confirmava-se a dissolução do Congresso Nacional e das Casas Legislativas estaduais e municipais e atribuía ao presidente o poder para nomear interventores para o governo dos estados. Percebe-se que as medidas centralizadoras do Governo Provisório de Vargas surgiram desde cedo. Com a dissolução do Congresso Nacional e das Casas Legislativas estaduais e municipais, Getúlio assumia não só o poder executivo como o legislativo, os estaduais e os municipais. (FAUSTO, 2006, p.186).

\subsubsection{Política Externa}

No plano das relações internacionais, o Governo Provisório instalado no Brasil não teve problemas para ser reconhecido internacionalmente. Isso se deve em razão dele ter garantido o cumprimento de todos os compromissos internacionais assumidos pelo país (CERVO, 2002, p.233). Ademais, as relações bilaterais com os EUA não sofreram alterações bruscas.

Neste período, o Estado brasileiro aumentou o poder de intervenção na economia com uma política cambial que favorecia a exportação dos produtos de sustentação econômica do país e diminuía os impostos alfandegários dos produtos externos inevitáveis ao 
desenvolvimento interno. Nota-se que as transformações econômicas e sociais fizeram o governo de Vargas adotar uma nova percepção do interesse nacional. Essas explicam, em grande parte, as mudanças ocorridas na política externa brasileira como: o reforço do pragmatismo e do seu sentido de instrumento do projeto de desenvolvimento nacional. Dessa forma, a política externa brasileira, nesse período, buscou formas de cooperação e barganhas voltadas para o interesse nacional. Esse era compreendido de maneira mais abrangente do que o da República Velha, pois procurava atender outros segmentos da sociedade. (CERVO, 2002, p.234).

Com a constituição de 1934, o governo de Vargas avançou na sua política de intervenção estatal na economia. Após esse período, houve nacionalização e estatização, por meio de contrato estatal, de empresas nacionais e internacionais por interesse da nação. Essas só foram possíveis em razão de três novos títulos que a Constituição trazia. Eles tratavam da ordem econômica e social, da família, da educação, da cultura e da segurança nacional. O primeiro dos novos títulos tinha intenções claramente nacionalistas. Esse previa a nacionalização progressiva das minas, das jazidas mineiras e das quedas de água, consideradas básicas ou essenciais à defesa econômica ou militar do Brasil. (FAUSTO, 2006, p.193).

\subsubsection{Política Interna}

A política interna brasileira, após a nova Constituição, possibilitou o surgimento de dois partidos que, refletindo as tendências da política internacional, dividiam em correntes ideológicas opostas. Esses eram: a Ação Integralista Brasileira - AIB, com orientação nazifascista, e a Aliança Nacional Libertadora - ANL, com tendência comunista. Houve um grande apoio popular aos novos partidos políticos, houve também interferência estrangeira em ambos os lados. Segundo o historiador Boris Fausto, a AIB conseguiu atrair um número considerável de participantes. Estimativas moderadas calculam entre 100 mil a 200 mil pessoas aderiram ao integralismo. (FAUSTO, 2006, p.195). Fausto também não deixa dúvida sobre a influência de Moscou sobre a formação da ANL. Segundo ele, a formação da Aliança se ajustou à nova orientação dada ao Partido Comunista Brasileiro - PCB que vinha diretamente do Komintern. (FAUSTO, 2006, p.197). 
Em novembro de 1935, após o governo ter mandado fechar todos os escritórios da ANL, alguns de seus partidários organizaram um movimento armado que sublevou três quartéis, era a Intentona Comunista. Entretanto, a revolta não se alastrou, ficando restrita a alguns militares que deram os primeiros tiros. A aventura fracassada da Intentona Comunista foi utilizada por Vargas como pretexto para o início maciço de uma campanha anticomunista no Brasil.

A suposta ameaça comunista e o clima de instabilidades, em razão do aumento nas agitações sociais por causa de problemas políticos e da crise financeira do café que gerou inflação, foram utilizados por Getúlio para aumentar o autoritarismo do governo que, juntamente com o apoio de parte da elite, de militares e de integralistas, lançou mão de um plano, o Plano Cohen.

O Plano, elaborado pelos integralistas e divulgado nos meios de comunicação em massa, levaria ao fim da democracia e ao surgimento de uma ditadura, Estado Novo, que se aproximava, em muitos aspectos, do modelo fascista de governo. Os efeitos do Plano Cohen, segundo Fausto, foram imediatos. O Congresso aprovou rapidamente o estado de guerra e a suspensão das garantias constitucionais por noventa dias. (FAUSTO, 2006, p.200).

Infere-se que o levante fracassado da ANL, em 1935, resultou em sérias conseqüências, pois abriu caminho para amplas medidas repressivas e para escalada autoritária do governo Vargas. (FAUSTO, 2006, p.198).

\subsection{O Estado Novo (1937- 1945)}

A ditadura do Estado Novo nasce em um momento histórico internacionalmente favorável aos regimes totalitários, com a ascensão do nazismo na Alemanha e do fascismo na Itália.

Em 1937, uma nova constituição é outorgada por Vargas. Houve um fortalecimento do executivo, o presidente passou a governar por decretos, a intervir na economia e a nomear governadores. Não houve resistência ou mobilizações às medidas adotadas por Vargas. Os movimentos populares e os comunistas tinham sido detidos e não possuíam meios para reagir, a classe dominante aceitava o golpe como algo inevitável e até mesmo benéfico. (FAUSTO, 2006, p.200). 


\subsubsection{Política Externa do Estado Novo}

O Estado Novo era amparado por um conjunto de forças internas que na maioria das vezes não se ajustava quanto às opções de política externa. Procurando atender às diferentes facções que o apoiavam - como a AIB, e aproveitando o cenário internacional para impulsionar o desenvolvimento interno, Vargas desenvolveu uma política externa de “eqüidistância pragmática”. O governo brasileiro negociava com quem lhe oferecesse as melhores condições e, com sua orientação pragmática, ele procurava tirar vantagem da rivalidade entre as grandes potências. (FAUSTO, 2006, p.208).

Getúlio estimulava as aproximações tanto com os EUA quanto com a Alemanha. Entretanto, ele evitava comprometer-se enquanto, aparentemente, avaliava as vantagens que poderia obter. Agindo dessa forma, ele buscava atender simultaneamente aos setores e aos grupos que gostariam de uma relação próxima aos estadunidenses e aos que buscavam uma parceria mais estreita com a Alemanha.

Tanto a Alemanha quanto os EUA buscavam ampliar sua influência na América Latina. As relações comerciais desses com os países latino-americanos ilustram bem a disputa entre eles. No caso do Brasil, os EUA insistiam nas premissas do livre comércio, os alemães ofereciam as vantagens do comércio compensado. O governo, com sua política externa pragmática, procurou beneficiar-se de ambas as possibilidades. Na historiografia é consenso afirmar que o Governo de Vargas fez “jogo duplo” em relação aos Estados Unidos e à Alemanha, no período que antecede à Segunda Guerra Mundial. A finalidade desse "jogo duplo” do Brasil era conseguir maior poder de barganha para o governo. (CERVO, 2002, p.234).

O comércio compensado ${ }^{3}$ era interessante aos industriais brasileiros. Ele possibilitava um maior controle do mercado interno, não permitindo que esse fosse invadido por mercadorias concorrentes alemãs. Ademais, o comércio compensado atraia os militares interessados no reaparelhamento das forças armadas, pois possibilitava contratos para fornecimento de material bélico. (CERVO, 2002, p.255). Dessa forma, enquanto não conquistasse o conhecimento técnico necessário para desenvolver sua indústria, o Brasil comprava, pelo sistema de compensação, ou seja, troca de produto por produto, armas e máquinas produzidas na Alemanha. (TOTA, 2005 p.26).

\footnotetext{
${ }^{3}$ Sistema de importação e exportações feitas à base de troca de mercadorias, cujos valores eram contabilizados nas “caixas de compensação” de cada país. (CERVO, 2002, p.254).
} 
Enfim, pode-se dizer que as transações com a Alemanha eram atraentes não só para certos grupos exportadores como também para os que defendiam a necessidade de modernizar e industrializar o país, como os militares. (FAUSTO, 2006, p.209).

As vantagens oferecidas pelos alemães com seu comércio compensado tinham uma explicação: os nazistas e os fascistas tinham interesse em aliar-se à ditadura brasileira não apenas por razões ideológicas ou pela presença aqui de grandes colônias de imigrantes alemães e italianos, mas por motivos estratégicos, tratando-se de um país americano. Durante toda a década foram feitos vários movimentos de simpatia recíproca, entre o governo alemão e o brasileiro, além de acordos especiais para comércio e uma grande encomenda de armamentos à fábrica alemã Krupp.

Em 1935, as relações Brasil-Alemanha atingem dimensões imprevisíveis. As relações comerciais, policiais, políticas, diplomáticas e militares chegam a determinado patamar que desperta temor nos EUA. A imprensa estadunidense chama atenção para essa estreita relação Brasil-Alemanha. Isso faz com que Washington oponha-se aos planos alemães, sobretudo pelo comércio. (SEITENFUS, 2003, p.10 - 11).

Os EUA, com sua defesa ao livre comércio, firmaram o tratado de 2 de fevereiro de 1935. Esse, com base na cláusula de "nação mais favorecida”, reduziu ou até mesmo isentou produtos importantes na pauta de exportação do Brasil como o café e o cacau. Em contrapartida, o Brasil concedeu favores alfandegários aos EUA. O acordo foi alvo de diversas críticas, pois muitos afirmavam que ele seria prejudicial ao desenvolvimento da indústria nacional e de praticamente eliminar a concorrência entre os fornecedores de produtos industrializados. (CERVO, 2002, p.255).

Conclui-se que o governo de Vargas praticava tanto o comércio compensado com a Alemanha quanto o livre comércio com os EUA. Entretanto, tanto um quanto o outro era caracterizado pelo relacionamento desigual e assimétrico com o Brasil. (MOURA, 1980, p.62).

O governo brasileiro, nesse período, encontrava-se dividido. As lideranças militares admiravam o ideário, o modelo econômico e o poderio bélico projetados pela Alemanha. Tanto o Ministro da Guerra, General Eurico Dutra, quanto o Chefe do Estado Maior, General Góes Monteiro, buscavam preservar os vínculos comerciais e a cooperação militar com o governo alemão. Outros colaboradores de Vargas valorizavam o modelo de vida estadunidense. Entre esses, os mais importantes eram Valentim Bouças, representante da IBM no Brasil e o chanceler do Estado Novo - Oswaldo Aranha. (FAUSTO, 2006, p.210). 
Para Seitenfus, até o fim de 1937, a política externa brasileira era marcada pela improvisação e ausência de linha de conduta. O Brasil possuía somente um papel importante no movimento Pan-americano, que naquele momento era considerado como aspecto menor das relações internacionais. (SEITENFUS, 2003, p.305). Todavia, a escolha de Oswaldo Aranha para comandar o Itamaraty, em 1938, marcou a evolução da política externa e a organização do Ministério. A entrada de Aranha no governo e a eliminação definitiva da AIB no cenário político nacional em 1937, por meio de decreto que determinava o fechamento de todos os partidos políticos, marcaram a reviravolta da política externa brasileira do período. (SEITENFUS, 2003, p.309).

Durante a gestão de Aranha, 1938 a 1944, foram fundidas em uma só as carreiras diplomáticas e consulares, ampliadas e aperfeiçoadas as funções da Secretaria de Estado; concedida particular atenção aos órgãos do comércio exterior, dos assuntos consulares e da política de imigração.

Oswaldo Aranha tinha bastante liberdade para a elaboração da política externa brasileira. Isso era possível em razão de um acordo tácito que ele mantinha com Vargas, aliás, seu amigo. O acordo era que Aranha não se envolveria na política interna do país e Vargas o deixaria com as mãos inteiramente livres nas questões externas. Dessa forma, em 1938, o chanceler brasileiro começou a desenvolver uma forte atividade política pró-americana. Essa tinha como base sua grande admiração pelos EUA e pelo presidente Roosevelt, bem como as péssimas relações que mantinha com a embaixada alemã. (SEITENFUS, 2003, p.309).

Aranha empenhou-se para que o Brasil mantivesse uma política externa de alinhamento aos EUA. Sua posição baseava-se em convicções adquiridas durante os anos de permanência em Washington. Além de sua admiração pela democracia estadunidense, ele estava convencido de que a liderança dos EUA tornava-se imprescindível para a paz mundial. A associação do Brasil com essa liderança lhe parecia a melhor opção para a política externa do país. Os esforços de aproximação do governo Roosevelt na busca do alinhamento hemisférico eram entendidos como uma grande oportunidade para o Brasil fortalecer sua presença tanto regional quanto internacional.

Aranha em diversas ocasiões manifestou qual deveria ser a política externa brasileira. De acordo com ele, a política externa do Brasil se resumia na seguinte orientação: apoiar os EUA em seu papel de potência mundial, em troca de apoio destes a supremacia do Brasil na América do Sul. (ALVES, 2005, p.151). 
A despeito de eventuais semelhanças políticas entre o governo brasileiro e o governo alemão e o italiano, e de membros governamentais simpatizantes com o modelo nazi-fascista, pode-se afirmar que o Brasil da década de 1930 era mais próximo dos EUA do que desses outros governos. Essa é a visão defendida pelos historiadores Ricardo Seitenfus e Amado Cervo. De acordo com eles:

Apesar das contradições existentes no seio do próprio governo, teria havido uma aposta brasileira nos Estados Unidos no final da década de 1930, portanto, num momento em que o mundo ainda era multipolar. (CERVO, 2002, p. 234).

[...] apesar das aparentes idas e vindas, a política externa brasileira obedece efetivamente, a partir de março de 1938, a rígidos princípios orientados por um entendimento com os Estados Unidos, percebido como necessário e indispensável. (SEITENFUS, 2003, p. 308).

Essa proximidade com os EUA não se tratava de fatalidade geográfica, mas era decorrência da forte presença econômica estadunidense no Brasil. Os EUA eram o maior parceiro comercial do país e seus empréstimos eram essenciais para o equilíbrio financeiro do Brasil em razão da crescente escassez de capitais europeus à medida que se aproximava a guerra. Ademais, faltava à Alemanha de Hitler condições objetivas para manter as demandas brasileiras (CERVO, 2002, p.255).

Há, ainda, de se considerar o crescente interesse por parte dos EUA, no período Roosevelt, em uma maior aproximação com a América Latina e na Política Externa da Boa Vizinhança. Finalmente, não se pode deixar de ressaltar o lastro histórico que existia no relacionamento entre Brasil e EUA. Todavia, e a despeito de todos esses fatores, Vargas continuava a ter fortes vínculos comerciais com a Alemanha.

Conclui-se que o “jogo duplo” e a ambigüidade de Vargas e de seu governo, as meias-voltas nas negociações, as dificuldades com os EUA e a manutenção dos contatos com a Alemanha faziam parte da tentativa do governo de dar maior peso ao pequeno poder de barganha brasileiro no sistema internacional. (SEITENFUS, 2003 p.311). No entanto, o decorrer da Segunda Guerra Mundial colocaria fim à política externa de "eqüidistância pragmática” que durou de 1935 a 1941. (MOURA, p.135 1980).

No início do conflito, Getúlio tentou manter a mesma política externa vigente, isso ficou claro na cobertura da guerra pelos meios de comunicação. O governo do Estado Novo determinou que a imprensa e o rádio permanecessem neutros ao divulgarem notícias sobre a 
guerra. Entretanto, o mundo assumia uma divisão mais nítida e a política externa exigia compromissos mais claros. Vargas e o Brasil necessitavam se definir.

Cada vez mais ficava claro que se tratava de uma guerra em escala mundial, e os estrategistas estadunidenses se preocupavam com a defesa de seu país. Roosevelt não queria a presença de inimigos ou aliados deles tão próximos, na América Latina. Para os EUA, as Américas tinham de se transformar em uma fortaleza do hemisfério e do próprio EUA. (TOTA, 2005, p.46). Portanto, do lado dos estadunidenses, a colaboração brasileira ganhou importância a partir do início da guerra em função de novos interesses estratégicos que se converteram em instrumento de negociação para Vargas.

O ano de 1940 foi decisivo para Vargas e seus aliados. As pressões dos estadunidenses para contar com o Brasil no já esperado envolvimento deles na guerra aumentaram. (ALVES, 2005, p.159). Dessa forma, após anos de pressões diplomáticas dos EUA, e, sobretudo, depois do início da guerra, o comércio com a Alemanha diminuiu consideravelmente e o país intensificou suas trocas comerciais com o grande vizinho americano. A partir dessa época, o relacionamento entre os dois países ganhou densidade nos campos econômico, militar e cultural, e o governo brasileiro procurou maximizar seu poder de barganha com os EUA para obter compensações econômicas e militares.

Além disso, a maioria da população brasileira, que sempre sofrera as influências culturais dos EUA, da França e da Inglaterra, parecia estar a favor da entrada na guerra contra o Eixo - Alemanha, Itália e Japão.

\subsection{Cooperação Brasil - Estados Unidos}

As relações bilaterais entre Brasil e EUA no século passado passaram por diferentes situações e atitudes. Da aproximação à indiferença, da desconfiança à aliança militar, da cooperação à competição, nas diversas fases de desenvolvimento de um relacionamento que remonta ao período anterior à independência do Brasil. Na esfera da sociedade e da economia, essas relações tornaram-se crescentemente intensas, sobretudo nas áreas culturais e nos investimentos privados, à medida que o Brasil se inseria cada vez mais nos circuitos internacionais. Contudo, o vínculo de cooperação entre EUA e Brasil nunca fora de tamanha intensidade como nos anos de 1940 e 1941. Esse é o ponto de vista defendido pelo pesquisador Seitenfus: "Durante o segundo semestre de 1940 e ao longo do ano de 1941, os 
Estados Unidos e o Brasil fortaleceram seus vínculos, como jamais o haviam feito.” (SEITENFUS, 2003, p.236).

Um dos pontos que levou o Brasil a se definir na Segunda Guerra foi a conquista de uma grande indústria siderúrgica. A Alemanha acenou com a possibilidade de fornecer os recursos e a tecnologia necessária, mas o início do conflito logo inviabilizou esse fornecimento. Embora, a construção da siderúrgica não estivesse na pauta do modelo econômico estadunidense para a América Latina, os EUA, em 1940, fizeram um acordo com o governo brasileiro que daria origem à Companhia Siderúrgica Nacional - CSN, em Volta Redonda, no Rio de Janeiro. A usina era o preço de obtenção da boa vontade brasileira para com as exigências estadunidense. (MOURA, 1991, p.20). Dessa forma, Vargas conseguiu vender o alinhamento do Brasil aos EUA em troca de uma grande siderúrgica. Ademais, somavam-se os entendimentos para o reequipamento das Forças Armadas Brasileiras.

Para os EUA, tornava-se crucial assegurar uma base militar na costa do nordeste do Brasil que apoiasse as operações dos Aliados no Norte da África e mantivesse a linha de suprimentos de materiais estratégicos. Além disso, o saliente nordestino ocupa posição geográfica importante no sistema defensivo hemisférico. Getúlio Vargas sabendo disso aproveitou o momento e procurou - como contrapartida da cooperação, obter vantagens concretas para o desenvolvimento econômico nacional como recursos e tecnologia estadunidense para a construção da CSN. (CERVO, 2002, p.259).

Nota-se que a retórica pan-americanista e as medidas concretas - como a construção da CSN - foram utilizadas por Washington para ganhar a América Latina no sentido de incluí-la no seu sistema de poder.

A opção por uma política de solidariedade hemisférica orientou o Brasil na Terceira Reunião de Consulta de Chanceleres Americanos. Realizada em janeiro de 1942, no Rio de Janeiro, a conferência teve como objetivo principal aprovar uma recomendação para que as repúblicas americanas rompessem relações com os países do Eixo. O rompimento de relações diplomáticas do Brasil com o Eixo, anunciado pelo chanceler Oswaldo Aranha, foi recompensado pelos estadunidenses por créditos suplementares para a exploração da indústria de matérias-primas brasileiras e pela concessão de um fundo de US\$ 200 milhões para as Forças Armadas nacionais adquirirem armas nos EUA por meio do Lend-Lease (empréstimo e arrendamento). (ALVES, 2005, p.160).

Em represália ao rompimento das relações do Brasil com os países do Eixo, seis embarcações comerciais brasileiras foram torpedeadas por submarinos alemães. Centenas de pessoas morreram nos ataques, a guerra atingia o Brasil de modo mais drástico que o Eixo 
podia conseguir. (ALVES, 2005, p.161). O resultado direto desses ataques, primeiramente, foi reconhecer a existência de um estado de beligerância com a Alemanha e a Itália em 22 de agosto. Em 31 de agosto de 1942, a beligerância transformou-se em estado de guerra entre o Brasil, a Alemanha e a Itália. (ALVES, 2005, p.161).

A importância do apoio brasileiro a Washington foi sublinhada em janeiro de 1943, quando o presidente Roosevelt visitou a base de Natal. Seu encontro com Vargas marcou o momento da maior aproximação entre os dois países durante a guerra.

No âmbito diplomático, a colaboração entre o Brasil e os EUA foi favorecida pelos esforços do embaixador Carlos Martins em Washington, nos anos 1938 - 45, e pelo do embaixador americano Jefferson Caffery a serviço no Rio de Janeiro nos anos 1937 - 44.

\subsection{Brasil e a Segunda Guerra Mundial}

A participação do Brasil na Segunda Guerra Mundial foi motivada mais por questões comerciais e econômicas do que por políticas e ideológicas. A participação efetuou-se em três modalidades: o fornecimento de produtos estratégicos para o esforço bélico dos aliados, a cessão de bases aéreas e navais, no nordeste brasileiro, para operações de abastecimento e transporte das forças armadas estadunidenses e o envio de uma força expedicionária ao campo de operações europeu.

A história dessa participação, desde as relações diplomáticas, que resultaram no alinhamento à política hemisférica estadunidense e na declaração de guerra ao Eixo, até as conseqüências econômicas, políticas e sociais, revelam a dimensão das dificuldades de um país pequeno ${ }^{4}$ - como o Brasil de então - para envolver-se diretamente em um conflito daquela magnitude e de inserir-se nas esferas decisivas da política internacional.

Cronologicamente, a primeira forma de participação na guerra foi na qualidade de fornecedor de produtos primários de interesse estratégico para os Aliados. O Brasil era para esses, fundamentalmente, fornecedor de matérias-primas. Produtos essenciais como a borracha e o quartzo brasileiro adquiriram um papel vital na defesa do continente. (TOTA, 2005, p.53).

\footnotetext{
${ }^{4}$ Pequeno refere-se ao poder e ao nível de capacidade possuídos pelo Estado em relação ao todo existente no sistema internacional.
} 
A segunda modalidade de participação brasileira na guerra foi a cessão de bases aéreas e navais, na região nordeste, para as forças armadas dos EUA. Antes mesmo do início da guerra, havia um temor da instalação de bases do Eixo na América do Sul por parte dos estrategistas estadunidenses. O nordeste brasileiro tornou-se um dos pontos estratégicos mais importantes da guerra. Seu controle marítimo e aéreo permitiu posição privilegiada nos combates do Atlântico Sul, vitais para reverter a posição dos Aliados na África, preservar suas linhas de suprimento a salvo de ataques do Eixo e, principalmente, manter a guerra longe do continente americano. A recém-criada Força Aérea Brasileira - FAB e a Marinha de Guerra do Brasil, dentro de suas limitações, participaram de patrulhamentos e comboios de proteção a embarcações mercantes, no litoral brasileiro.

Contudo, de toda participação brasileira, a contribuição mais direta para o esforço Aliado foi o envio de uma divisão de exército e um grupo de aviação de caça, para lutar na Itália, entre 1944 e 1945. A idéia de mandar tropas brasileiras para lutar fora do continente tomou corpo na segunda metade de 1942 - depois dos torpedeamentos de navios mercantes brasileiros, e foi reforçada pelas aspirações da política externa brasileira em participar mais ativamente da reorganização do mundo após o fim do conflito, garantindo pelo menos uma hegemonia no continente sul-americano.

Fruto principal da aproximação política e militar entre Brasil e EUA, a criação da Força Expedicionária Brasileira - FEB e sua incorporação às tropas Aliadas foram cercadas de reservas por lideranças militares estadunidenses e inglesas. Eles não aceitavam a idéia de enviar tropas novatas, com treinamento deficiente e costumes poucos conhecidos, para enfrentar inimigos experientes e acostumados aos terrenos e climas da região dos combates.

Percebe-se que a idéia de mandar combatentes ao exterior foi uma proposta exclusivamente brasileira e essa não contava como elemento necessário do plano estadunidense de defesa do hemisfério. (GAMBINI, 1977, p.147). Entretanto, o futuro da aliança entre Brasil e EUA poderia ser comprometido e assim, a incorporação de tropas brasileiras às forças aliadas foi autorizada. A criação da FEB foi, portanto, muito mais uma necessidade política que militar. Segundo o historiador Gambini, a permissão para o combate e o treinamento da FEB era vista pelo departamento de guerra estadunidense como um privilégio concedido ao seu mais importante aliado americano (GAMBINI, 1977, p.147).

Em 2 de maio do mesmo ano, as tropas alemãs se renderam em toda a Itália. A guerra acabara para os brasileiros. Segundo o historiador Boris Fausto, mais de 20 mil homens lutaram na Itália e morreram em combate 454 brasileiros (FAUSTO, 2006, p.211). 
A colaboração, durante a guerra, entre forças militares do Brasil e dos EUA, estreitou ainda mais os vínculos entre os dois países. Neste contexto, o governo brasileiro concordou com o pedido de Washington, em julho de 1945, e declarou guerra ao Japão. Essa aproximação entre oficias brasileiros e estadunidenses foi responsável pela colaboração militar entre os dois países que seguiu após o fim do conflito. (CERVO, 2002 p.266 - 267).

No meio diplomático nacional acreditava-se que tal participação asseguraria uma posição prestigiosa nas conferências de paz do pós-guerra. Ganhava força a idéia de que o status de poder associado favoreceria os interesses brasileiros em futuras negociações internacionais. Entretanto, tal suposição logo se esvaziou. A partir de 1945, a preocupação das potências vencedoras, dos EUA em particular, concentrou-se na reconstrução européia e na contenção do comunismo. Essas novas prioridades deixavam pouco espaço para as aspirações latino-americanas no processo de reordenamento mundial.

Ademais, a falta de atenção que a América Latina recebeu, logo após o fim da Segunda Guerra por parte do governo estadunidense, deve-se, também, a uma confusa política externa adotada, inicialmente, por Harry Truman, presidente estadunidense, sucessor de Roosevelt que morreu antes do fim do conflito. Esse é o ponto de vista do historiador Alves, ele argumenta:

Imediatamente após o fim da Segunda Guerra Mundial, no entanto, o descaso dos Estados Unidos deu-se mais por confusão do que por desígnio político. Roosevelt morreu ainda durante a guerra e seu sucessor, Harry Truman, não tinha conhecimento nem força política para imprimir imediatamente marca própria à política externa norte-americana. Pairou então muita dúvida sobre a validade dos compromissos norte-americanos dos tempos de guerra. (ALVES, 2005, p.165).

No retorno ao Brasil, os expedicionários foram recebidos com festas em todo o território nacional. Por sua vez, uma minoria bastante ativa de oficiais de carreira juntou-se aos movimentos de oposição ao Estado Novo que se articulavam ao redor do esquema próEUA. Ambos realizaram um esforço em conjunto que colaborou para a deposição de Vargas e o fim de seu regime em outubro de 1945. (GAMBINI, 1977, p.149).

Conclui-se que, do ponto de vista da política interna, a participação na guerra e, por conseguinte, a maior participação do Brasil nas relações internacionais foram elementos chaves para o início do processo de redemocratização nacional. A maior inserção brasileira no cenário internacional impulsionou as oposições e abriu caminho a divergências no interior do governo. (FAUSTO, 2006, p.211 - 212). Imediatamente após o fim da guerra, a contradição 
do Estado Novo se aflorou. Como um governo ditatorial - com aspectos fascistas, lutou ao lado de Estados que defendiam um modelo democrático? As pressões de o alto comando militar colocou fim ao governo de Vargas e ao Estado Novo, impondo assim sua renúncia por intermédio de um golpe militar. 


\section{CAPÍTULO III}

\section{POLÍTICA EXTERNA DE BOA VIZINHANÇA}

\subsection{Antecedentes da Política Externa de Boa Vizinhança}

Implementada durante os governos do democrata Franklin Delano Roosevelt - 1933 a 1945, a Política Externa de Boa Vizinhança tornou-se a estratégia de relacionamento com a América Latina naquele período. Sua principal característica foi o abandono da prática intervencionista que prevalecera nas relações dos EUA com a América Latina desde o final do século XIX.

No fim do século XIX, durante o governo Theodore Roosevelt, a necessidade de defender a América Latina da influência de outras potências ocasionou a revisão da política externa estadunidense tradicional no que tange a alianças internacionais, ao fortalecimento das Forças Armadas e ao uso estratégico do Canal do Panamá. Diante do desafio apresentado pela Alemanha ao poderio naval inglês, impunha-se a revisão da Doutrina Monroe ${ }^{5}$ em termos mais realistas por meio do estabelecimento de sólidos laços e de intervenções nos países latino-americanos. (GAMBINI, 1977, p.29).

Dessa forma, em 1904, os EUA acrescentaram à Doutrina Monroe o chamado “corolário Roosevelt.” De acordo com esse, os EUA enfrentariam a concorrência européia nos países americanos aplicando os mesmos métodos de dominação. Apesar de o “corolário Roosevelt” ter sido aplicado somente na América Central e o Caribe, ele provocou a revolta e despertou o sentimento antiamericano em toda América Latina. Esse sentimento não era nada favorável aos interesses estadunidenses na região. (SARAIVA, 2007, p.152).

Com a chegada ao poder de Franklin Delano Roosevelt, a política externa estadunidense sofreu várias mudanças. Adotou-se a negociação diplomática e a colaboração econômica e militar com o objetivo de impedir a influência nazi-fascista na região, de manter a estabilidade política no continente e de assegurar a liderança estadunidense no hemisfério ocidental. Os EUA perceberam que a América Latina reagiria mais favoravelmente às suas

\footnotetext{
${ }^{5}$ A Doutrina Monroe (1823), que conferia aos Estados Unidos a proteção do Hemisfério Ocidental contra a expansão dos impérios europeus, tinha por base material o apoio naval britânico. (GAMBINI, 1977, p.29).
} 
intenções se eles respondessem positivamente às necessidades dos seus vizinhos americanos, ou seja, a idéia de dominação pela força deveria ser substituída pela noção de reciprocidade. (GAMBINI, 1977, p.46).

\subsection{O nascimento da Política Externa de Boa Vizinhança}

Como foi visto, o início do século passado foi marcado por tensões diplomáticas entre os EUA e a América Latina, em razão das intervenções estadunidenses no Caribe e na América Central.

Na primeira década do século, o presidente estadunidense Woodrow Wilson (1913 1921) se elegeu com uma proposta humanista. Para diminuir as tensões com a América Latina, Wilson afirmava que os EUA não reconheceriam governos impostos pela força, além da adoção de um "Pan-americanismo” multilateral. Wilson negava tanto a política do presidente anterior William H. Taft, conhecida como “diplomacia do dólar”, baseada em intervenções em regiões onde os negócios estadunidenses estivessem ameaçados, quanto a do “porrete” de Theodore Roosevelt. A diplomacia wilsoniana, apesar de conseguir modestos

avanços, foi responsável por preparar o caminho para a da Boa Vizinhança de Roosevelt. (SARAIVA, 2007, p.151).

Nas primeiras décadas do século passado, havia, na América Latina, uma forte onda de nacionalismo e de movimentos de esquerda. Na Argentina, havia um governo militar claramente de direita, no Chile e no Peru, os governos eram de tendências esquerdistas. No cenário político peruano o antiamericanismo ganhava cada vez mais força, havia a Aliança Popular Revolucionária Americana - APRA um partido que tinha como bandeira o antiimperialismo estadunidense. No Brasil, a Crise de 1929, acabou com a oligárquica “República Velha” (1899 - 1930) e abriu caminho para Getúlio Vargas e seu governo populista-nacionalista. (HOBSBAWM, 1994, p 109 - 10).

A Crise de 1929 foi outro motivo que levou os EUA a repensarem sua política externa. O presidente Roosevelt foi o principal agente dessa verdadeira revolução nos assuntos externos. Em seu discurso de posse, Roosevelt já deixou claro de como seria a relação dos EUA com a América Latina e com os demais países. 
No campo da política mundial eu dedicarei esta nação à política da boa vizinhança - uma vizinhança que resulte do respeito mútuo e, devido a isso, respeite o direito dos outros - uma vizinhança que respeite suas obrigações e respeite a santidade dos seus acordos para com todos os seus vizinhos do mundo inteiro. (Discurso de posse, 4 de março de 1933). (Schilling, 2002)

A adoção dessa realpolitik, por parte dos estadunidenses, tinha como um dos seus objetivos controlar, de forma pacífica, o crescente antiamericanismo na América Latina e impulsionar o comércio entre as nações da região com os EUA. Ademais, não era interesse de Roosevelt e de seus assessores mais próximos que os EUA envolvessem em uma intervenção armada na região. (TOTA, 2005, p.49).

Para o presidente Roosevelt, a política externa com o Canadá era o modelo a ser seguido pelos EUA na América Latina. Em discurso proferido na cidade de Chautauqua, Nova York, em 14 de agosto de 1936, ele disse:

[...] o mais nobre monumento à paz e à boa vizinhança econômica e à amizade social não é feito de bronze ou pedra - é a fronteira que une os Estados Unidos e o Canadá: mais de três mil milhas de amizade, sem arame farpado, canhão ou soldado, e sem passaporte ao longo de toda ela. É a confiança mútua que constrói esta fronteira. Estender esta mesma sorte de confiança por toda a América é o nosso objetivo. (discurso em Chautauqua, Nova York, em 14 de agosto de 1936) (Schilling, 2002).

Em um estudo realizado pelo economista Lloyd Gardner sobre a Política Externa de Boa Vizinhança de Roosevelt, percebe-se que essa era o reconhecimento de que os EUA deveriam agir com mais tática com seus vizinhos americanos. As intervenções militares e nas políticas internas na verdade atrapalhavam o uso efetivo do poder político e econômico estadunidense. (GAMBINI, 1977, p.36).

Na VII Conferência Pan-americana realizada em Montevidéu - 1933, a delegação dos EUA, já atendendo os princípios da Política de Boa Vizinhança, adotou um discurso conciliatório, As antigas reivindicações latino-americanas de não-intervenção, que vinham sendo feitas desde a Conferência de Havana - 1928, foram aceitas. Dessa forma, o Secretário de Estado dos EUA, Cordell Hull, assinou a Convenção de Direitos e Deveres dos Estados, cujo artigo 8. ${ }^{\circ}$ estipulava que "nenhum Estado tem direito de intervir nos assuntos internos ou externos de outro". (GAMBINI, 1977, p.47).

Além disso, a Emenda que mantinha Cuba como protetorado foi revogada e no mesmo ano, 1934, os marines estadunidenses retiraram-se do Haiti. Em 1936, tanto o Haiti 
quanto o Panamá deixaram de ser protetorados dos EUA. Em 1941, foi eliminado o controle estadunidense sobre as alfândegas da República Dominicana. Ao adotar tais medidas, pode-se afirmar que o democrata Roosevelt se tornou o presidente dos EUA mais popular na América Latina até então.

Nesse período, houve mais quatro importantes Conferências: Buenos Aires (1936), Panamá (1939), Havana (1940) e Rio de Janeiro (1942). Os temas e as questões debatidas nessas conferências demonstravam o processo gradual que os EUA enfrentavam para adotar uma nova política externa. Essa deveria passar a imagem - para os demais países americanos - de ser menos belicosa que as anteriores, além de que ela seria garantida pela consolidação de laços econômicos duradouros. A diplomacia estadunidense voltava a usar a retórica da união Pan-americana. A presença de uma guerra dava a impressão de um perigo externo e funcionava como motivo para a aproximação dos países americanos em torno dos EUA. (GAMBINI, 1977, p.47 - 48).

Ademais, para Gambini havia outro fator a levar em consideração nas Conferências, era o comércio. O pesquisador defende que os resultados apresentados pelas várias conferências realizadas sugerem uma constante dominante. Essa era que os países latinoamericanos somente tornariam aliados dos EUA à medida que esses substituíssem a Alemanha como compradores de produtos de exportações e como fornecedores de manufaturados e equipamentos para a região. (GAMBINI, 1977, p.43).

\subsection{Os objetivos da Política Externa de Boa Vizinhança}

A Política Externa de Boa Vizinhança na América Latina tinha, a princípio, dois objetivos: recuperar os efeitos da Crise de 1929 sobre a economia estadunidense e conter a crescente presença da Alemanha nazista no comércio com os países da região, especialmente com o Brasil e a Argentina. (HILTON, 1983, p.32). Outro fator importante dessa política era, como já foi visto, combater o crescente antiamericanismo na região.

O aumento da influência alemã na América Latina ocorreu, como já foi mostrado, em razão do comércio compensado. Com essa política comercial de trocas diretas que dispensava qualquer moeda, a Alemanha conseguia dentro de sua capacidade abastecer os países latino-americanos em suas necessidades de máquinas e de manufaturados, comprometendo-se, em troca, adquirir seus produtos primários. O Brasil, aliás, tinha se 
tornando depois de 1934; em 1937 e 1938 o principal parceiro comercial da Alemanha na América do Sul. Além dos contratos de armamentos com a fábrica Krupp, o governo brasileiro estabeleceu, por meio da polícia federal, ligações com a Gestapo - polícia secreta nazista. Essas visavam a coordenação de medidas anticomunistas nos dois países. As relações Brasil-Alemanha chegaram a tal ponto que, no final de 1937, depois da implantação do Estado Novo, o governo nazista até cogitava de tentar persuadir Vargas a assinar o Pacto Antikomintern. (HILTON, 1983, p.30 - 31).

Ademais, após a Crise de 29, o modelo de democracia capitalista liberal estava sendo constantemente questionado. O sucesso de Hitler e do modelo nazi-fascista de recuperar a economia alemã e de desenvolver eficientes mecanismos de disciplina social atraiam a atenção de alguns militares e da sociedade civil latino-americana, que os viam como alternativas ao americanismo. Na América Latina, como já se mostrou, houve o surgimento de grupos de clara tendência fascista a partir de 1932, por exemplo, a Ação Integralista Brasileira - AIB, o mais importante movimento fascista das Américas. Esses grupos e a simpatia de alguns militares pelo modelo fascista que cercavam o general Justo, na Argentina, Gaitán, na Colômbia e Vargas, no Brasil, preocupavam enormemente círculos políticos e militares nos EUA. (HOBSBAWN, 1992, p.136).

Para Hobsbawm, a crescente simpatia pelo fascismo europeu na América Latina e a rejeição do americanismo na região ocorreram pelos seguintes fatos: após 1914, os EUA não eram mais vistos como um aliado das forças internas do progresso e como um contrapeso diplomático para as nações imperialistas e ex-imperialistas, como França, Inglaterra e Espanha, pelo contrário, os EUA começaram a serem identificados também como imperialistas. A reação desses à Revolução Mexicana, o surgimento da indústria de petróleo e da banana, a “diplomacia de canhoneiras” e de marines introduziu um antiimperialismo estadunidense na política latino-americana que permitiu o fortalecimento de grupos simpatizantes do fascismo. (HOBSBAWN, 1992, p.136).

Os EUA precisavam reagir a essa expansão da influência germânica e do fascismo nos seus vizinhos americanos. A cooperação comercial, a solidariedade continental e o Panamericanismo deveriam ser reforçados. A importância do Brasil, dentro desse quadro, era fundamental. (ALVES, 2002, p.78).

Com o prenúncio da Segunda Guerra Mundial e posteriormente com a entrada dos EUA nela, os países da América Latina tornaram-se prioridade para a defesa estadunidense. O Brasil recebeu uma atenção especial de Washington em razão do medo de ataques do Eixo no nordeste brasileiro, ponto estratégico para os Aliados, e da forte presença de colônias de 
imigrantes alemães e italianos no Brasil. O medo dos estrategistas estadunidenses de perderem o nordeste brasileiro para os países do Eixo fez com que essa região, alguns meses antes do início das hostilidades na Europa, fosse incluída na zona de defesa dos próprios EUA. (HILTON, 1983, p.31 - 32).

Incentivar a solidariedade hemisférica de forma a enfrentar a influência dos regimes nazi-fascistas e de consolidar os EUA como grande potência e como modelo a ser seguido eram as metas da Política Externa da Boa Vizinhança para América Latina. Percebe-se que essa se apoiava em um esquema econômico que visava claramente o estabelecimento de um sistema continental pan-americano para anular um suposto sistema pan-germânico para a região. (GAMBINI, 1977, p.43). Sendo assim, o tema de integração dos países americanos para resistir ao imperialismo europeu voltou a ter destaque na diplomacia estadunidense.

Para combater a rejeição ao American way of life, como modelo para o desenvolvimento da América Latina, e para diminuir a influência nazista na região, os EUA começaram a utilizar, neste momento, de forma significativa e com eficiência os meios de comunicações e a política cultural. Os EUA ofereciam, aos países da região, bolsas de estudos e treinamento, havia traduções de livros, divulgação de músicas e filmes estadunidenses aqui, além da realização de uma intensa propaganda contra a Alemanha, frisando o tema da ameaça nazista ao hemisfério. (HILTON, 1983, p.32). (GAMBINI, 2007, p. 150 - 151).

Nas palavras da historiadora Mauad, a consolidação e a defesa de uma aproximação com as nações latino-americanas contaram com dois ingredientes fundamentais: política e propaganda. O próprio presidente Roosevelt fazia questão de apresentar os bons vizinhos latino-americanos nas suas conversas no rádio. Ele utilizava seu forte apelo político enquanto os meios de comunicação ficavam encarregados de apresentar o perfil e de criar um tipo latino-americano. A América Latina era visualizada por meio de um conjunto de representações que era fortemente marcada pelo avanço das técnicas de imagens e sons: o cinema, o rádio e a fotografia. (MAUAD, 2005, p.56).

Nota-se que a mídia foi utilizada como meio de divulgar o Pan-americanismo, de incentivar a solidariedade entre os povos americanos e de combater o avanço nazista na região. Os meios de comunicação transformaram-se em verdadeiros instrumentos de Estado das relações internacionais com a América Latina. Isso se deu, pois, a propaganda e os meios de comunicação são peças chaves em tempos de guerra e assumem uma função psicológica fundamental. Essa é: reforçar o moral dos seus aliados e de erodir o moral do inimigo. (DUROSELLE, 1992, p.213). 
3.4 A criação do Office of the coordinator of Inter-American Affairs - OCIAA

Criado em 16 de agosto de 1940, inicialmente para garantir e ampliar as bases das relações comerciais entre as Américas, o órgão recebeu o nome de Office of Commercial and Cultural Relations between the American Republics, passando a se chamar, a partir de 23 de março de 1941, Office of Inter-American Affairs - OIAA. Em 30 de julho de 1941, tem seu nome mudado para Office of the Coordinator of Inter-American Affairs - OCIAA. (TOTA, 2005, p.190).

O OCIAA era encarregado, entre outras coisas, de elaborar e de desenvolver projetos de aproximação cultural entre os EUA e a América Latina. (TOTA, 2005, p. 50). Vinculado ao Conselho de Defesa Nacional dos EUA, o OCIAA tinha como diretor o empresário milionário estadunidense Nelson Rockefeller, proprietário, entre outros bens, da Standard Oil. (TOTA, 2005, p.50).

O jornalista do The New York Times, James Reston, em um artigo publicado no jornal que ele representava, afirmou que os objetivos do OCIAA eram:

[...] persuadir a América Latina a cerrar fileiras com nossas forças em ações defensivas contra a ameaça alemã [...] convencê-las de que temos a resposta para as questões econômicas e militares [...] e acima de tudo convencer todos os latinoamericanos de que a Política de Boa Vizinhança não é um expediente temporário para nos ajudar nessa dura tarefa, mas uma atitude sincera e permanente, exatamente o contrário de nossa “diplomacia do dólar” e do Destino Manifesto, no século XIX. (TOTA, 2005, p.186).

O Órgão possuía setores de comércio, finanças, assessoria econômica, transportes, agricultura, administração, saúde pública, relações culturais e comunicação. Os setores de relações culturais e comunicação tinham subdivisões que tratava de música, de cinema, de imprensa, de literatura, de rádio e de arte. Entretanto, a sua estrutura era extremamente complexa, com diversas subdivisões com sedes nas principais cidades dos EUA e na maioria dos países latino-americanos. O OCIAA pode ser considerado uma das agências mais bem preparadas na época da guerra e que tinha capacidade de mudar constantemente, dependendo da conjuntura. (TOTA, 2005, p.91).

No Brasil, o mais importante país da região para os EUA, as metas almejadas pelo OCIAA foram três: informação, saúde e alimentação. Essas tinham funções definidas de 
penetração e de convencimento ideológico por meio do controle dos meios de comunicação, do investimento intensivo em publicidade e do fomento de uma estrutura assistencialista para a saúde e educação, principalmente no nordeste, região onde seriam instaladas as bases estadunidenses. Ademais, todas essas ações do governo estadunidense visavam também divulgar o progresso e o desenvolvimento dos EUA. Os EUA deveriam ser apresentados, segundo a visão de Nelson e de sua equipe, como um país possuidor do segredo do progresso e que estava disposto a compartilhar com seus vizinhos americanos. As transmissões de rádio, o cinema, os projetos de saneamento e de saúde e os programas econômicos tinham esse sentido paradigmático de que os EUA eram o modelo a ser seguido na região. (TOTA, 2005, p.180).

\subsubsection{OCIAA e os meios de comunicação}

Os EUA, antes de entrarem definitivamente na guerra, estavam comprometidos com outra batalha, a da comunicação internacional contra os nazistas e fascistas.

Por meio de programas radiofônicos, revistas, (Time, Life e Seleções Reader's Digest), cinema e anúncios publicitários o OCIAA atuava em resposta à propaganda nazista na América Latina. Esses divulgavam informações positivas dos EUA e de sua política externa. Eles promoviam o Pan-americanismo, o comércio e passavam uma imagem favorável das demais "Repúblicas” americanas. (TOTA, 2005, p. 55).

Percebe-se que produtos culturais produzidos por um país e vendidos aos demais conseguem divulgar estilos de vida, conceitos, visões e até mesmo o próprio país. Em tempos de guerra a existência de uma política cultural é fundamental para conquistar mentes e corações. Logo, cultura e propaganda passam a serem tratadas e consideradas como assunto estratégico como qualquer outro. (TOTA, 2005, p. 53).

Nessa perspectiva, o uso dos meios de comunicação na Política Externa de Boa Vizinhança, para além de seu caráter diplomático, é uma das primeiras exportações de versões idealizadas do American way of Life, com a clara tentativa de influenciar audiências estrangeiras por meio da atração do soft power.

No ponto de vista comercial, o uso dos meios de comunicação pela Política Externa de Boa Vizinhança conseguiu acelerar o comércio e a importação de produtos fabricados nos EUA, com destaque para automóveis e eletrodomésticos. Os anúncios publicitários 
vinculados na América Latina difundiam a impressão de que os produtos fabricados nos EUA eram essenciais para a vida quotidiana e faziam parte do progresso.

O diretor do OCIAA, Rockefeller, acreditava que o futuro dos investimentos nos países da região dependia da venda de duas coisas: de produtos e do modo de vida estadunidense. Portanto, o sucesso no setor econômico dependia, primeiramente, do êxito no campo ideológico. (TOTA, 2005, p.54).

Um marco dessa forma de pensar de Rockefeller foi o lançamento da Coca-Cola na América Latina. Sendo uma marca importante dentro dos EUA, a Coca Cola buscou ressaltar em suas campanhas publicitárias o Pan-americanismo e o American Way of Life, porém sem deixar de focar na conquista do mercado da região. A empresa de refrigerante, ao se estabelecer no Brasil, presenteou um ministro de Estado com uma caixa de seu produto que acompanhava uma carta relacionando a Coca-Cola ao Pan-americanismo. A carta dizia que o produto representava um elo de fraternidade entre as Américas. (MOURA, 1988, p. 72).

\subsubsection{Rádio}

A Divisão de Rádio do OCIAA era a menina dos olhos de Rockefeller. (TOTA, 2005, p.74). De acordo com diretor do órgão, esse meio de comunicação poderia alcançar um público mais amplo e de todas as classes sociais. (TOTA, 2005, p.74).

No rádio, o OCIAA apresentava programas transmitidos diretamente dos EUA ou por estações locais. Alguns programas de rádios fizeram bastante sucesso como: Voz da América, O Brasil na Guerra, A Família Borges, Barão Eixo e o noticiário mais famoso da época O Repórter Esso.

O Repórter Esso era patrocinado pela empresa do diretor do OCIAA, Standard Oil Company, e transmitido para 14 países da América Latina. O noticiário ia ao encontro da perspectiva de Rockefeller sobre a política externa para a América Latina, o fundamental seria fomentar, no Brasil e no restante das Américas, a criação de canais culturais que permitissem o intercâmbio efetivo com os EUA.

No Brasil, o Repórter Esso se instalou em 1941 e se tornou o principal noticiário radiofônico brasileiro. Ele era transmitido em várias edições diárias e vinculava, além de notícias, propaganda político-ideológica e cultural com a intenção de influenciar o governo e a sociedade brasileira. (KLÖCKNER, 2004, p.01). 
Durante a guerra, uma grande parte dos programas de rádio procurava manifestar a onipresença, a união, a superioridade e a resistência material e moral dos Aliados sobre um adversário fraco e fragmentado. (TOTA, 2005, p.77).

A maioria dos programas de rádio feitos nos EUA e transmitidos no Brasil contava com apoio do Departamento de Imprensa e Propaganda - DIP. Segundo o historiador TOTA, o DIP colaborou estreitamente com o OCIAA, durante a guerra, chegando a ceder parte do tempo do programa Voz do Brasil para divulgar notícias sobre a guerra e os EUA. (TOTA, 2005, p.76 - 77).

A respeito da vinculação da Política Externa de Boa Vizinhança e de informações sobre o Brasil nas rádios estadunidenses, Tota descreve algumas passagens do programa News of the World ou Evening News.

\begin{abstract}
O Brasil aparecia com mais destaque no noticiário. O próprio presidente Roosevelt mandava uma bem-humorada mensagem ao seu "largest neighbor that is standing shoulder to shoulder with the United States”. A importância do Brasil e de seus produtos para os Estados Unidos era sempre enfatizada. [...] Na seqüência entrava um comercial: "Sempre que você tomar um café brasileiro, você estará comprando a Política da Boa Vizinhança. Compre café brasileiro... se você for a favor da Política da Boa Vizinhança”. (TOTA, 2005, p. 109).
\end{abstract}

Infere-se que o rádio foi sem dúvida um grande aliado dos EUA para divulgar sua política externa e que essa foi, em grande parte, divulgada pela radiodifusão. (TOTA, 2005, p. 94).

\title{
3.4.1.2 Cinema
}

A indústria cinematográfica foi outro meio de comunicação utilizado na divulgação da política externa do governo de Roosevelt. O cinema é a arma de comunicação mais poderosa, pelo uso da imagem, para convencer um povo em guerra sobre princípios e valores, além de mostrar a superioridade técnica e moral perante o inimigo.

Rockefeller criou, em 1940, uma seção de cinema na Divisão de Comunicação do OCIAA, a Motion Picture Divison - MPD. A MPD tinha entre suas atividades a distribuição de produções cinematográficas na América Latina e nos EUA. A MPD incentivou os estúdios a não caracterizar os latino-americanos como vilões ou bandidos, esses deveriam ser os nazi- 
fascistas. A sensualidade da mulher e a coragem e simpatia do homem latino-americano foram enaltecidos. De acordo com Tota, a divisão de cinema tinha as seguintes funções: promover a produção interna de filmes (curtas e longas), de cinejornais sobre os EUA e as “outras Américas” e distribuí-los para os países da região. Além de combater por todos os meios o cinema produzido pelo Eixo por sua indústria cinematográfica alemã, UniversumFilm AG - Ufa. (TOTA, 2005, p. 65). Para tanto, o OCIAA estimulou a criação de histórias e de filmes de Walt Disney, com a presença de personagens inspirados nos países latinoamericanos como uma forma de atrair a simpatia desses.

O grande investimento do OCIAA na produção de filmes estava vinculado à capacidade desse meio em servir como plataforma para a diplomacia estadunidense e em atingir uma massa analfabeta de forma mais eficiente que o rádio.

Dessa forma, a produção cinematográfica dos EUA, que era concentrada em Hollywood e regida por códigos que tinham como preocupação central a preservação dos valores morais, sociais e religiosos na nação, passou, a partir de 1933, a atuar em sintonia com os ideais e valores da política do governo de Roosevelt. Assim, a divisão de cinema do OCIAA começou a requerer cada vez mais material para Hollywood. (TOTA, 2005, p. 62).

O OCIAA realizou parcerias com os grandes estúdios de Hollywood e fez vultosos investimentos na produção de filmes. Os estúdios de cinema, da mesma forma que ocorreu com os outros meios de comunicações utilizados pelo OCIAA, tinham como tarefa: estreitar os laços entre os países da América, difundir a cultura, o estilo de vida, os produtos, os valores dos estadunidenses pelo continente e neutralizar a influência nazi-fascista. Entretanto, para Hollywood, pode-se afirmar que a Política da Boa Vizinhança tinha outro significado. Ela era um modo de melhorar o mercado de distribuição e tentar compensar pela perda do circuito europeu durante a guerra. Contudo, para OCIAA os meios de comunicação, incluindo o cinema, eram poderosos instrumentos de diplomacia.

Artistas renomados foram utilizados pelo governo estadunidense e pelo o OCIAA na divulgação da Política Externa de Boa Vizinhança. Como exemplo, pode-se destacar: Walt Disney, Tyrone Power, Lana Turner, John Ford, Genevieve Naylor, Orson Welles e Carmen Miranda. (TOTA, 2005, p 61 - 64).

O OCIAA dava tamanha importância ao cinema que, em alguns países da América Latina, havia caminhões e projetores responsáveis de exibir as produções da MPD nas cidades do interior onde não havia cinemas. Desse modo, a propaganda do OCIAA conseguia atingir um maior número de pessoas. (MAUAD, 2005, p.58) 
Aos poucos a cinematografia de Hollywood ganhou o mercado no Brasil, assim como os produtos que vinham vinculados a ela. Portanto, a educação visual fazia parte da política externa do governo Roosevelt que se dedicava a atrair a simpatia e o apoio dos países latino-americanos.

\subsection{O fim do OCIAA e da Política Externa de Boa Vizinhança}

A morte de Roosevelt, 1945, as vitórias dos Aliados e o desaparecimento do perigo de invasão do subcontinente americano por tropas do Eixo fizeram com que a preocupação e a atenção dos EUA para com a América Latina fossem perdendo força a partir do quarto ano da Guerra. (TOTA, 2005, p.183). O fim da Segunda Guerra Mundial, em 1945, trouxe uma nova ordem mundial. A URSS e os EUA, os grandes vencedores, emergiram como grandes potências. Dessa forma, a preocupação estadunidense não era mais a expansão do nazifascismo, mas era conter o avanço dos soviéticos e do comunismo.

A Guerra Fria fazia da China, da Coréia e até mesmo da Índia áreas crucias para a política externa dos EUA, pois lá o avanço do comunismo era mais perigoso e iminente do que aqui. (TOTA, 2005, p.190). Nota-se que a atenção dos políticos e estrategistas estadunidenses deslocou da América Latina para a reconstrução e o combate do avanço comunista na Europa e na Ásia.

Enquanto existiu, o OCIAA foi extremamente eficaz em alcançar seus principais objetivos. Ele conseguiu manter uma imagem favorável aos EUA, enaltecer os valores do progresso, divulgar produtos e combater a ameaça nazi-fascista na região. Entretanto, a principal vitória do OCIAA foi a escolha de seu programa de "conquista dos corações e mentes” dos latino-americanos, em vez da intervenção e submissão militar. (TOTA, 2005, p. 180).

Após todos esses fatos, a agência, que fora criada em 1940, teve suas funções encerradas, em maio de 1946, por um ato do presidente Harry Truman. A grande fábrica de ideologias, criada pelo presidente Roosevelt e administrada Nelson Rockefeller, foi fechada. Ela não tinha mais serventia na nova política externa para América Latina. (TOTA, 2005, p. 190). 


\section{CONCLUSÃO}

Na primeira parte, procurou-se analisar e contextualizar o cenário, tanto internacional quanto brasileiro, em que a Política Externa de Boa Vizinhança foi implementada. Posteriormente, pretendeu-se realizar uma reflexão das razões e motivos que levaram os EUA e o presidente Franklin Delano Roosevelt a adotarem tal opção de Política Externa para a América Latina no período de 1933 - 1945. Por último, o estudo buscou evidenciar a importância e os serviços prestados pelos meios de comunicação, sobre o amparo do OCIAA, para a eficiência da Política Externa de Boa Vizinhança. Notou-se que a época estudada foi palco de grandes mudanças sociais, sendo uma delas a evolução e a completa transformação da forma de se comunicar. Hoje, a imprensa ou a mídia exerce sua força e seu poder de persuasão em todas as esferas da sociedade.

No primeiro capítulo, procurou-se analisar o período de entre guerras (1919 - 1939) e o surgimento de uma nova guerra. O entre guerras foi marcado por grandes instabilidades, resultado dos acordos pós - Primeira Guerra Mundial e pela crise do modelo capitalista democrático-liberal. A Crise de 1929 mereceu atenção especial em razão de sua magnitude e de sua importância. Poucos países atravessaram a Grande Depressão sem sofrer mudanças internas, o que demonstra a grande influência da economia estadunidense naquela época.

Para solucionar as mazelas da Crise, o mundo desenvolvido dividiu-se em dois caminhos diferentes. Um liberal e democrático - representado, principalmente, pelo presidente estadunidense Roosevelt e seu New Deal - $e$ outro totalitário e com forte controle das massas - representado pelo regime fascista italiano e alemão. Com o colapso do liberalismo econômico e das instituições políticas liberais, com o avanço dos regimes fascistas e com o questionamento da Alemanha ao status quo do sistema internacional - instaurado na Conferência de Paris - 1919, afirma-se que o entre guerras foi um período preparatório para um novo conflito que, todavia, envolveria a maior parte das nações do mundo desta vez.

No segundo capítulo, tentou-se demonstrar o cenário brasileiro no período governado por Vargas (1930 - 1945). Esse coincide, grosso modo, com o período do presidente estadunidense Roosevelt (1933 - 1945) e o da sua Política Externa da Boa Vizinhança. Observou-se a instauração do governo provisório de Vargas e posteriormente do regime autoritário, Estado-Novo. Em ambos, a ambigüidade e o autoritarismo prevaleceram na política do governo. Percebeu-se que a opinião pública brasileira, seguindo as tendências da política internacional, encontrava-se divida em correntes ideológicas opostas: fascismo, 
comunismo e capitalismo - liberal. A política externa do período, a inserção do Brasil no sistema internacional e as negociações brasileiras para participar da Segunda Guerra mereceram destaque.

O governo brasileiro adotou uma orientação pragmática e tratou de negociar com quem lhe oferecesse melhores condições. A idéia era de tirar vantagem da rivalidade entre as grandes potências. A orientação pragmática e o “jogo-duplo” da política externa brasileira de Vargas, que procurava as melhores condições e que barganhava o apoio do Brasil com a Alemanha e com os EUA, podem levar erroneamente a crer que o Brasil apoiaria o Eixo na Segunda Guerra Mundial. Entretanto, comprova-se que a despeito de eventuais semelhanças políticas entre o governo brasileiro, o governo alemão e o italiano, e de membros governamentais simpatizantes com o modelo nazi-fascista, as relações do Brasil da década de 1930 eram mais próximo dos EUA do que desses outros regimes. Por último, pretendeu-se analisar a cooperação Brasil - EUA na Segunda Guerra Mundial e suas características, além da participação brasileira na Guerra. Afirma-se que aquele momento de colaboração com os Aliados no esforço de guerra foi o período em que a relação bilateral Brasil-EUA esteve mais próxima.

O terceiro e o último capítulo dialogam com os dois anteriores. Os dois primeiros servem como base para compreender como e quais motivos fizeram os EUA a adotarem a Política Externa de Boa Vizinhança para América Latina e qual era a importância do Brasil nessa.

Para melhor analisar a Política Externa de Boa Vizinhança e sua representatividade na diplomacia estadunidense, foi feito uma pequena retrospectiva das relações EUA e América Latina nos períodos antecedentes ao presidente Franklin Delano Roosevelt. Esforçou-se para demonstrar o surgimento e os objetivos almejados pela Política Externa de Boa Vizinhança. Todavia, o maior destaque desse capítulo foi a criação, a formação e a atuação do OCIAA. A maior atenção a esse órgão, controlado pelo empresário milionário estadunidense Nelson Rockefeller, deve-se a sua extrema importância para a Política Externa da Boa Vizinhança. Conhecendo seu funcionamento, seu modo de agir e de pensar, conhece a própria essência da política externa dos EUA para os países latino-americanos no período.

O OCIAA foi extremamente eficaz em alcançar seus principais objetivos. O Órgão conseguiu, com auxilio dos meios de comunicação, manter uma imagem favorável aos EUA, enaltecer os valores do progresso, divulgar produtos e, em certo modo, o American Way of Life entre os países latino-americanos e combater a ameaça nazi-fascista na região. No entanto, a principal vitória do OCIAA foi a escolha de seu programa de "conquista dos 
corações e mentes” dos latino-americanos, em vez da intervenção e submissão militar. (TOTA, 2005, p. 180). No entanto, vale ressaltar que a mídia, como forma de diplomacia, e a utilização dos meios de comunicação, na elaboração da política externa de um país, carecem de estudos acadêmicos na área de relações internacionais. (VIZENTINI, 2001).

Certamente, os sucessos do uso dos meios de comunicação pelo OCIAA são grandes na época da Política de Boa Vizinhança. Entretanto, examinando-os de perto, percebe-se que eles não podem ser separados de certas condições de receptividade como: miséria, decepção, humilhação, esperança de bem-estar ou de liberdade. Por mais eficazes que pareçam as técnicas de ação psicológica, é incorreto imaginar que elas estão à disposição de qualquer aparelho, visando qualquer fim. É preciso um conteúdo político e uma ressonância na população.

Infere-se que, a partir da Política Externa de Boa Vizinhança, a relação brasileira com os EUA se consolidou. Ademais, ela nunca chegou ser desfeita ou desmentida, mesmo a despeito de fases mais ou menos turbulentas na política externa do Brasil. A hegemonia ideológica do Pan-americanismo, tão pregado no período da Segunda Guerra Mundial, só parece ter se esgotado com o fim da Guerra-Fria e a supressão da ameaça de revoluções comunistas na região. (ALMEIDA, 2006, p.223).

Enfim, esse estudo procurou recordar os elaboradores de política externa de hoje, momento de transição e de dúvidas do cenário mundial - fatores que geram as condições de receptividade - que é possível divulgar - de modo muito mais eficiente - estilos de vida, conceitos, visões, países, além de estimular e atrair mentes sem a necessidade de apelar para uma “diplomacia de canhoneiras.” A escolha de Roosevelt e de sua equipe por uma política externa, que alcançou seus objetivos e obteve sucesso, baseadas no soft power, na política de reciprocidade e na consolidação de laços econômicos duradouros é prova histórica disso. 


\section{REFERÊNCIA BIBLIOGRAFICA}

ALVES, Vágner Camilo. O Brasil e a Segunda Guerra Mundial: história de um envolvimento forçado. São Paulo: Loyola, 2002.

DUROSELLE, Jean-Baptiste Todo Império Perecerá. Brasília: UnB, 2000.

FAUSTO, Boris. História Concisa do Brasil. São Paulo: EDUSP, 2002.

FREIRE, Bianca Medeiros. O Rio de Janeiro que Hollywood inventou. Rio de Janeiro: Jorge Zahar, 2005.

GAMBINI, Roberto. O duplo jogo de Getúlio Vargas: influência americana e alemã no Estado Novo. São Paulo: Símbolo, 1977.

HILTON Stanley. A guerra secreta de Hitler no Brasil: A espionagem alemã e a contraespionagem aliada no Brasil, 1939-1945. Rio de Janeiro: Nova Fronteira, 1983.

HILTON Stanley. O Brasil e a Crise Internacional: 1930 - 1945. Rio de Janeiro: Civilização Brasileira S.A, 1977.

HOBSBAWN, Eric. Era dos Extremos: O breve século XX: 1914 - 1991. São Paulo: Companhia das Letras, 1995.

ISKANDAR, Jamil Ibrahim. Normas da ABNT. Curitiba: Juruá, 2003.

MILZA, Pierre. De Versailles à Berlin 1919 - 1945. Paris: Masson \& Armand Colin Éditeurs, 1996.

MOURA, Gerson. Autonomia na dependência: a política externa brasileira de 1930 a 1942. Rio de Janeiro: Nova Fronteira, 1980. 
Guerra Mundial. Rio de Janeiro: FGV, 1991.

. Tio Sam chega ao Brasil: a penetração cultural americana. São Paulo: Brasiliense, 1988.

PECEQUILO, Cristina. A política externa dos Estados Unidos. Porto Alegre: UFRGS, 2003.

SARAIVA, José F. Sombra (Org.). História das Relações Internacionais Contemporâneas: da sociedade internacional do século XIX à era da globalização. São Paulo: Saraiva, 2007.

SEITENFUS, Ricardo. O Brasil vai à Guerra. São Paulo: Manole, 2003.

TOTA, Antonio Pedro. O imperialismo sedutor: a americanização do Brasil na época da Segunda Guerra. São Paulo: Cia. das Letras, 2000.

\section{ARTIGOS E TESES}

ALMEIDA, Paulo Roberto. Entre a América e a Europa: a política externa do Brasil nos anos 1920. Revista Brasileira de Política Internacional, Brasília, vol. 49, $n^{\circ}$ 001, p.223, janeiro - junho 2006.

ALVES, Vágner Camilo. Ilusão desfeita: a “aliança especial” Brasil - Estados Unidos e o poder naval brasileiro durante e após a Segunda Guerra Mundial. Revista Brasileira de Política Internacional, Brasília, vol. 48, nº 001, p.151-177, janeiro - junho 2005.

ITUASSU, Arthur. Mídia e Relações Internacionais: a realidade simbólica. ITUASSU, Rio de Janeiro, novembro 2005. Disponível em http://www.ituassu.com.br/midiaeri.pdf. Acesso em: 20 de novembro de 2007.

KLÖCKNER, Luciano. O Repórter Esso e Getúlio Vargas. In: Congresso Brasileiro de Ciências da Comunicação, 27, 2004. Porto Alegre. Anais. São Paulo: Intercom, 2004. CDROM. 
MAUAD, Ana Maria. Genevieve Naylor, fotógrafa: impressões de viagem (Brasil, 19411942). Revista Brasileira de História, São Paulo, vol. 25, n49, p.43-75, junho 2005.

PECEQUILO, Cristina S. Paradigmas da Inserção Internacional do Brasil: A

Política Externa dos EUA. Conjuntura Internacional - PUC - MG, Belo Horizonte, setembro, $2003 . \quad$ Disponível em http://www.pucminas.br/imagedb/conjuntura/CNO_ARQ_NOTIC20060427175259.pdf?PHP

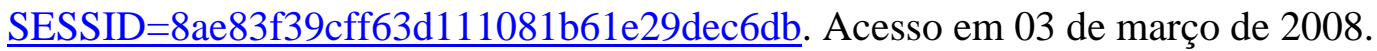

PINTO, Paulo A. Pereira. China e Índia - A Disputa por “Soft Power.” Mundorama Divulgação científica em Relações Internacionais, Brasília, dezembro, 2007. Disponível em: http://mundorama.net/2007/12/05/china-e-india-\%E2\%80\%93-a-disputa-por-E2\%80\%9Csoftpower\%E2\%80\%9D/. Acesso em 03 de março de 2008.

SCHILling, Voltaire. EUA, a Política da Boa Vizinhança de Roosevelt, São Paulo, abril, 2002.Seção Educação. Disponível em: http://educaterra.terra.com.br/voltaire/index_mundo.htm. Acesso em: 15 de dezembro de 2007.

VIZENTINI, Paulo. O Tibete e a Diplomacia de Hollywood. São Paulo, maio, 2001. Seção: Relações Internacionais por Paulo Vizentini. Disponível em: http://educaterra.terra.com.br/vizentini/artigos/artigo_31_2.htm. Acesso em: 15 de dezembro de 2007. 